\title{
ABUSO DO DIREITO DE VOTO AFIRMATIVO NA ASSEMBLEIA GERAL DE CREDORES
}

\author{
Dissertação de Mestrado \\ Orientador: Professor Doutor Manoel de Queiroz Pereira Calças
}

UNIVERSIDADE DE SÃO PAULO

FACULDADE DE DIREITO

São Paulo -SP

2018 

CAROLINA MANSUR DA CUNHA PEDRO

Abuso do direito de voto afirmativo na assembleia geral de credores

\section{Versão Original}

Dissertação de Mestrado apresentada à Banca Examinadora do Programa de Pós-Graduação em Direito, da Faculdade de Direito da Universidade de São Paulo, como exigência parcial para a obtenção do título de Mestre em Direito, na área de concentração de Direito Comercial, sob a orientação do Professor Doutor Manoel de Queiroz Pereira Calças

Universidade de São Paulo

Faculdade de Direito

São Paulo - SP

2018 



\section{CATALOGAÇÃO NA FONTE}

P372 Pedro, Carolina Mansur da Cunha.

Abuso do direito de voto afirmativo na assembleia geral de credores /

Carolina Mansur da Cunha Pedro. - 2018.

$155 \mathrm{f}$.

Orientador: Manoel de Queiroz Pereira Calças.

Dissertação (Mestrado) - Universidade de São Paulo. Faculdade de Direito.

1. Direito - Teses. 2. Falimentar - Teses. 3. Recuperação Judicial - Teses. I. Calças, Manoel de Queiroz Pereira. II. Universidade de São Paulo. Faculdade de Direito.. III. Título.

CDU 34(81)

Autorizo, apenas para fins acadêmicos e científicos, a reprodução total ou parcial desta dissertação, desde que citada a fonte. 

Nome: Pedro, Carolina Mansur da Cunha Pedro

Título: Abuso do direito de voto afirmativo na Assembleia Geral de Credores

Dissertação apresentada à Banca Examinadora do Programa de PósGraduação em Direito, na Faculdade de Direito da Universidade de São Paulo (USP), como exigência parcial para a obtenção do título de Mestre em Direito.

Aprovada em:

Banca Examinadora:

Presidente: Prof. Dr. Manoel de Queiroz Pereira Calças

Julgamento:

Presidente: Prof. Dr.

Julgamento:

Presidente: Prof. Dr.

Julgamento:

Presidente: Prof. Dr.

Julgamento: 

Aos meus queridos pais, ao meu marido Rodrigo e ao meu filho Theodoro. 



\section{AGRADECIMENTOS}

O presente trabalho reflete dissertação de Mestrado a ser defendida perante a Faculdade de Direito da Universidade de São Paulo, que contou com o incentivo e a contribuição de muitas pessoas.

Agradeço, especialmente, ao Professor Manoel de Queiroz Pereira Calças, notório conhecedor da teoria e da prática de recuperação judicial e falências, que me honrou com sua orientação, seus ensinamentos e sua convivência semanal durante essa jornada. Obrigada ainda pelo exemplo de dedicação, que certamente contribuiu para o desenvolvimento aprimoramento da minha vida acadêmica.

Sou grata aos Professores Francisco Satiro e Roberto Pfeiffer, que integraram a banca julgadora do exame de qualificação da presente dissertação, contribuindo para sua estruturação e seu desenvolvimento, com sugestões bibliográficas e ponderações muito apropriadas.

À amiga e Professora Renata Mota Maciel Madeira Dezem, exemplo de incansável dedicação à academia, pelas discussões frutíferas, pelas lições acadêmicas, por sua constante disponibilidade para contribuir com ideias, indicações bibliográficas e metodológicas, minha sincera gratidão.

Agradeço ao Professor Marcelo Sacramone, pela disponibilidade em discutir o tema aqui tratado e por suas contribuições com referências bibliográficas e observações.

Às amigas Ana Paula Aleixo, Maria Isabel Fontana e Natália Yasbek Orsovay, com quem tive o prazer de conviver durante os anos de desenvolvimento deste trabalho, compartilhando ideias e dividindo angústias. Não posso deixar de agradecê-las por tornarem essa jornada mais leve e menos solitária.

Minha gratidão à Sueli Costa, pelo imprescindível apoio, em especial na fase final.

Meu profundo agradecimento a meus pais, por dedicarem anos à minha formação e por sempre estimularem minha aplicação aos estudos. À minha mãe, especialmente, sou grata por cuidar de Theodoro durante a minha ausência. Esse projeto seguramente não seria possível sem o apoio de vocês.

Ao meu marido Rodrigo de Grandis, incentivador da minha dedicação à vida acadêmica e com quem compartilhei longas horas durante a jornada de elaboração dessa dissertação. Sou grata pelo seu apoio e por acreditar no meu potencial, certamente essa etapa não teria se concretizado sem você. 



\section{RESUMO}

PEDRO, Carolina Mansur da C. Abuso do direito de voto afirmativo na Assembleia Geral de Credores. 2018. 155 f. Dissertação (Mestrado) - Faculdade de Direito, Universidade de São Paulo, São Paulo, 2018.

A presente dissertação de mestrado se propõe a investigar o abuso do direito de voto favorável ao plano de recuperação. Em síntese, pretende-se analisar se podem existir situações de abuso do direito de voto favorável à aprovação do plano de recuperação judicial e se, em razão da ausência de mecanismos de intervenção jurisdicional sobre a deliberação dos credores, o voto abusivo favorável deixa de ser investigado pela doutrina e jurisprudência. Além dos capítulos destinados a introduzir o assunto e apresentar as conclusões da dissertação, o trabalho se dividirá em cinco partes. No capítulo 2, pretende-se tecer considerações sobre a ideia nuclear da teoria do abuso do direito e de como ele é disciplinado em nosso ordenamento jurídico. A terceira parte analisará os debates sobre a função do sistema de insolvência, procurando identificar a sua finalidade, bem como os interesses tutelados pelo processo de reorganização. A quarta parte, por sua vez, abordará a dinâmica da assembleia geral de credores e o papel atribuído aos credores dentro do processo de recuperação. O quinto capítulo se destina a pesquisar os limites da atuação jurisdicional no nosso ordenamento jurídico. Por fim, o último capítulo discorrerá sobre o abuso do direito de voto na recuperação judicial, analisando quais os parâmetros para sua caracterização, revelando hipóteses em que seria possível configurar o voto afirmativo e tentando estabelecer um paralelo entre os parâmetros do voto abusivo desfavorável e do voto abusivo afirmativo.

Palavras-chave: Direito Falimentar. Direito da Empresa em Crise. Recuperação Judicial. Assembleia de Credores. Abuso do direito de voto. 



\begin{abstract}
PEDRO, Carolina Mansur da C. Abuso do direito de voto afirmativo na Assembleia Geral de Credores. 2018. 155 f. Dissertação (Mestrado) - Faculdade de Direito, Universidade de São Paulo, São Paulo, 2018.

The current master's thesis sets forth the investigation on abuse of favorable vote to the reorganization plan. In summary, it intends to analyze if there may be situations of abuse of favorable vote upon the approval of the judicial reorganization plan and if, due to the absence of judicial intervention mechanisms regarding the creditor's deliberation, the favorable abusive vote is not investigated by the doctrine and case law. Besides the chapters aimed at introducing the subject and presenting conclusions to the thesis, the dissertation is divided in five parts. In chapter 2 , it intends to present considerations on the key idea over the theory regarding the abuse of right and how it is ruled in our legal system. The third part assesses the debates over the function of the insolvency system, in an attempt to identify its purpose, as well as the interests protected by the reorganization process. The fourth part, in its turn, envisages the approach towards the dynamic in general creditors' meeting and the role granted to the creditors within the reorganization process. The fifth chapter deals with the research on the limits of the judicial power from our legal system. Finally, the last chapter discusses the abuse of vote in the judicial reorganization, analyzing which standards are the basis for its nature, revealing hypothesis in which are possible to constitute the favorable vote and trying to stablish a comparison between the standards of unfavorable abusive vote and the favorable abusive vote.
\end{abstract}

Key words: Bankruptcy Law. Insolvency Law. Judicial Reorganization. General Meeting. Of Creditors. Abuse of vote. 



\section{SUMÁRIO}

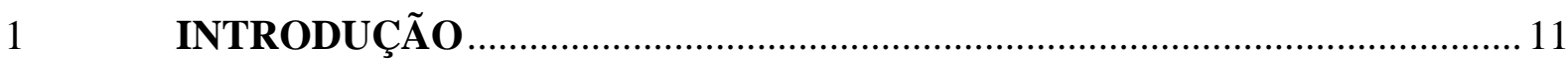

Tema a ser desenvolvido e suas limitações ..................................................... 11

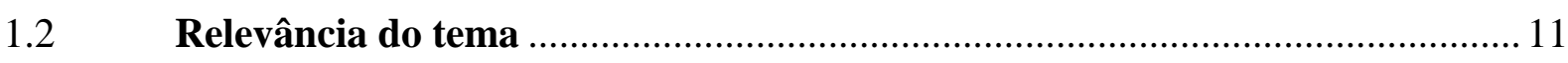

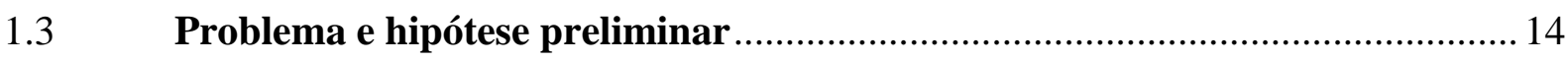

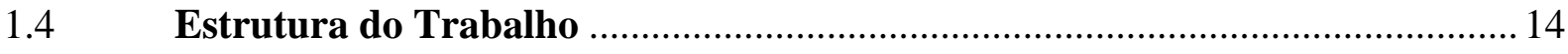

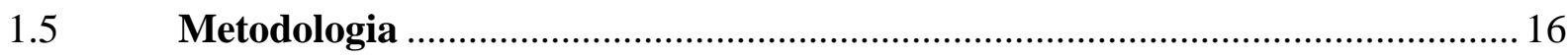

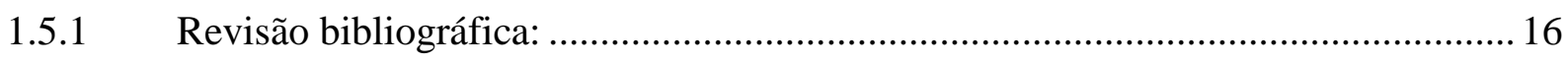

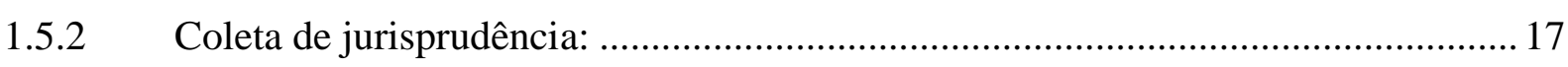

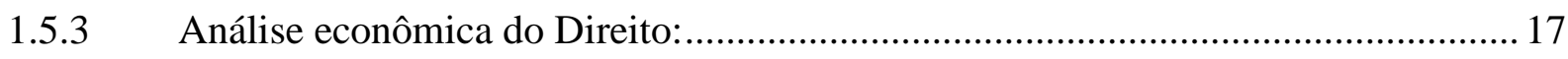

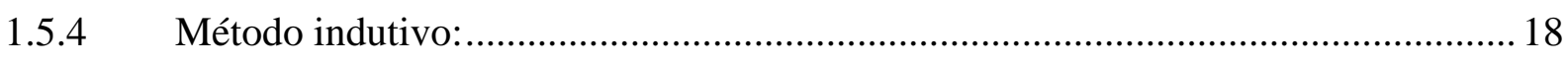

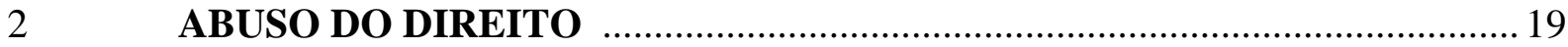

$2.1 \quad$ Breves considerações sobre o abuso do direito................................................ 20

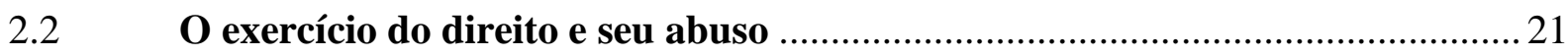

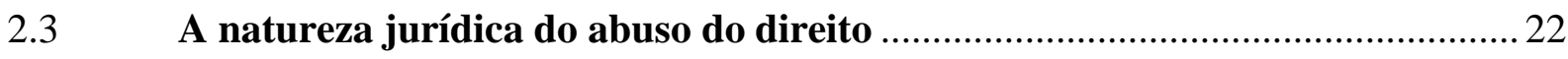

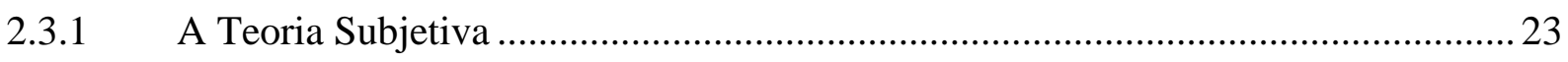

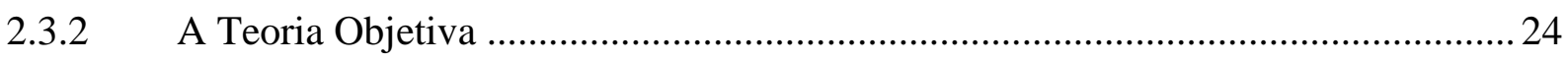

$2.4 \quad \mathrm{O}$ abuso do direito como categoria jurídica autônoma ……............................ 25

$2.5 \quad \mathrm{O}$ abuso do direito no ordenamento jurídico brasileiro …................................ 28

2.5.1 O abuso do direito no Código Civil ..................................................................... 28

2.5.1.1 O verbo “exercer” e sua extensão ............................................................................ 29

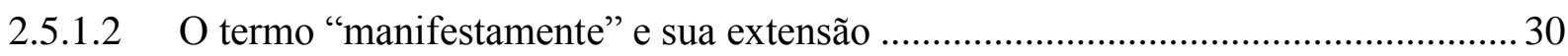

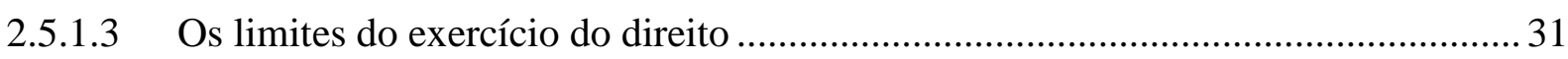

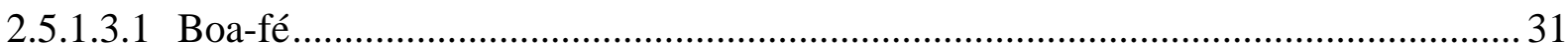

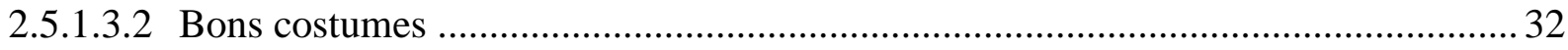

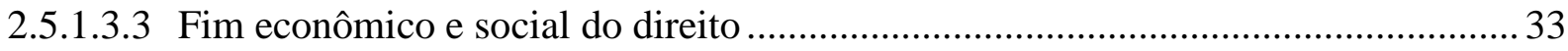

2.5.1.4 Efeitos jurídicos decorrentes da prática de atos abusivos ........................................ 34

2.5.2 O abuso do direito na Lei de Sociedades Anônimas................................................. 35

2.5.2.1 A formação da vontade nas sociedades anônimas ................................................. 36

2.5.2.2 Definição do interesse social na Lei $\mathrm{n}^{\circ}$ 6.404/1976 ............................................. 37

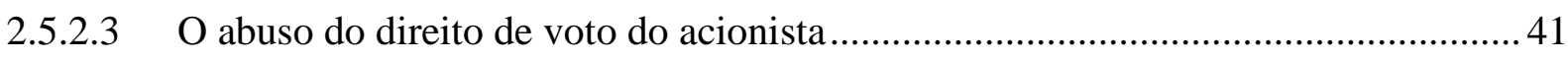

2.5.2.4 A figura do controlador e o abuso do poder de controle........................................ 42 

2.5.2.5 A sanção para as hipóteses de vícios de voto 44

3.1 Do início da valorização da preservação da empresa até o Chapter 11 …......... 46

3.2 O debate sobre a finalidade do procedimento de insolvência: tutela da atividade empresarial ou tutela do crédito

3.3 A finalidade do procedimento de reorganização nos diversos

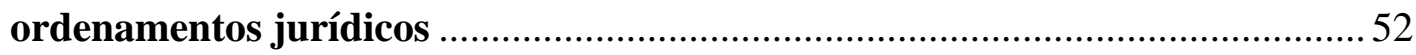

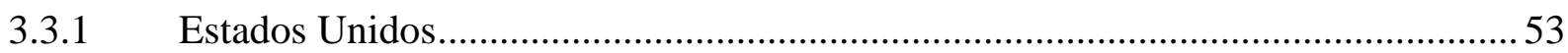

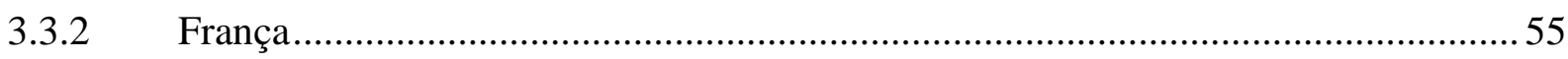

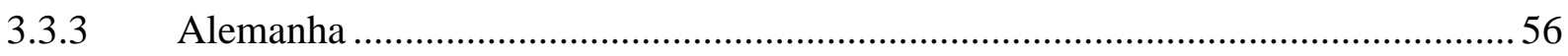

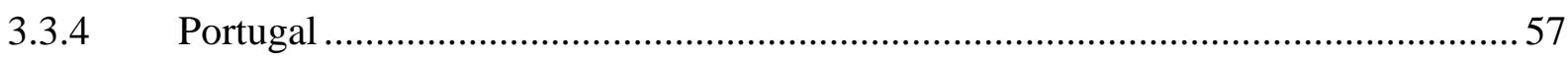

$3.4 \quad$ A Lei $\mathbf{n}^{\mathbf{0}}$ 11.101/2005 e a identificação dos interesses protegidos.......................58

3.5 Os interesses afetados pela recuperação judicial no Brasil............................... 60

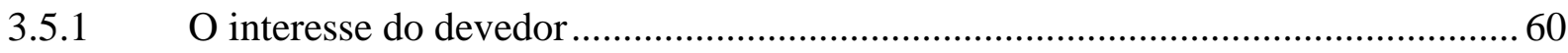

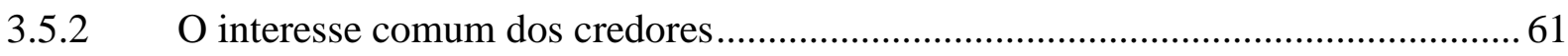

3.5.3 Outros interesses envolvidos na reorganização da empresa em crise ...................... 64

3.5.4 O interesse recuperacional: a preservação da empresa ......................................... 65

3.6 A falência como meio de preservação da função social da empresa ................. 67

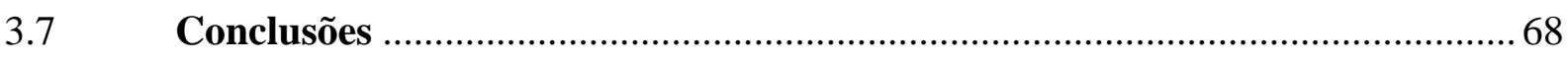

4 O PAPEL DOS CREDORES NA RECUPERAÇÃO JUDICIAL ..................... 69

4.1 A recuperação judicial como instrumento de negociação coletiva e a dinâmica da Assembleia Geral de Credores na recuperação judicial............... 69

Prevalência da vontade dos credores na recuperação ...................................... 71

Os limites do exercício do voto do credor ...................................................... 72

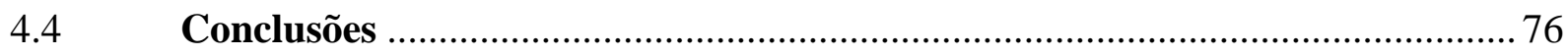

5 OS LIMITES DA ATUAÇÃO JURISDICIONAL SOBRE O EXERCÍCIO

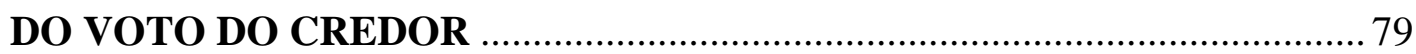

5.1 Breves considerações sobre a atuação jurisdicional ...................................... 79

5.2 A experiência nos sistemas de insolvência estrangeiros ................................. 81

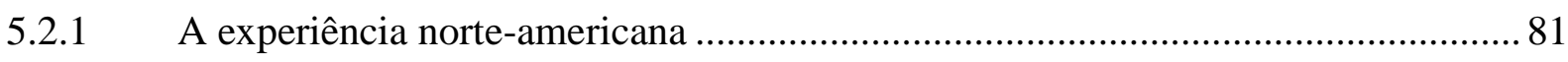

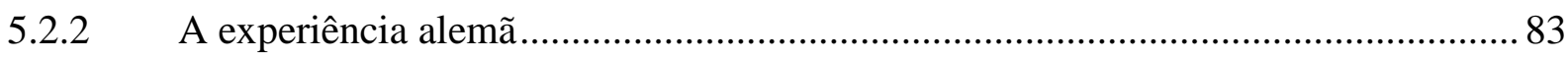

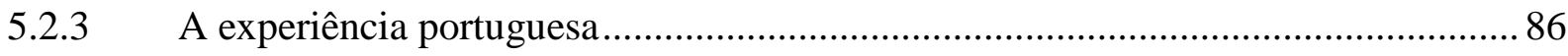

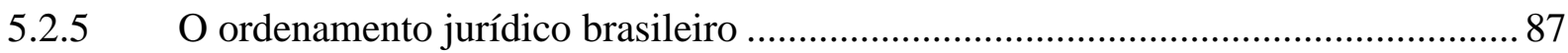



5.3 Parâmetros apontados pela doutrina brasileira para atuação jurisdicional

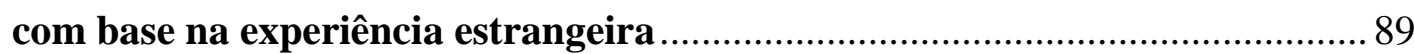

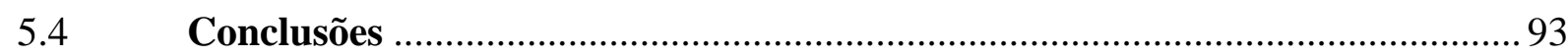

6 ABUSO DO VOTO NA ASSEMBLEIA GERAL DE CREDORES ….............99

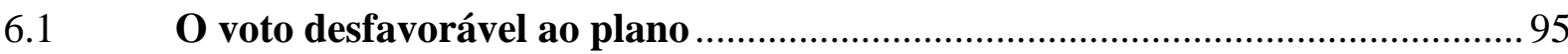

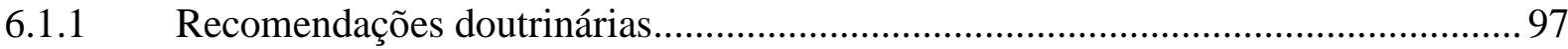

6.1.1.1 A necessidade de reforma do mecanismo do cram down ..................................... 97

6.1.1.2 Parâmetros para aferição do voto abusivo .............................................................. 98

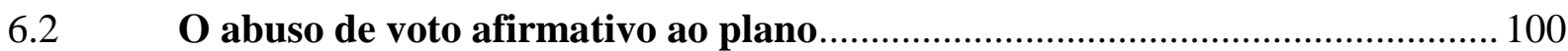

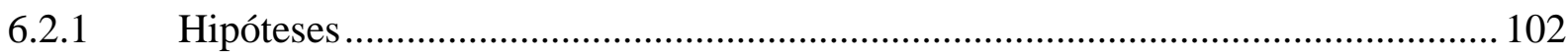

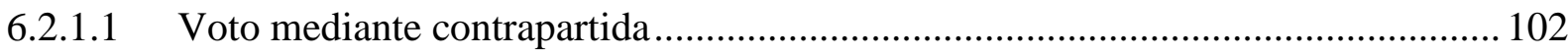

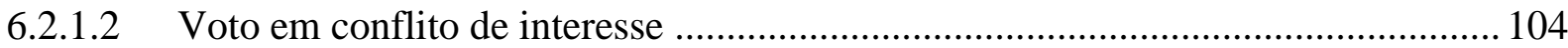

6.2.1.3 Abuso do credor detentor de posição dominante ................................................. 105

6.2.1.4 Credor com créditos em mais de uma classe ...................................................... 106

6.2.1.5 Voto proferido pelo cessionário de créditos do devedor ..................................... 107

6.2.1.6 Credor com risco de sujeição à ineficácia ou revogação em caso de falência....... 110

6.2.1.7 Credor com garantia prestada por terceiros.........................................................111

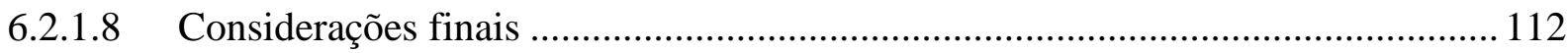

Sanções ao abuso do direito de voto .............................................................. 112

6.4 O abuso do direito de voto na Assembleia Geral de Credores e a

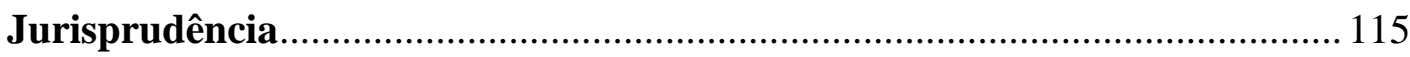

6.4.1 O reconhecimento pelo Tribunal da licitude do voto que rejeita o plano de recuperação judicial

6.4.2 O reconhecimento pelo Tribunal do abuso do voto que rejeita o plano de

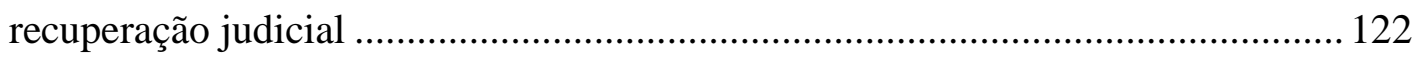

6.4.3 O voto afirmativo e afastamento de abusividade pelo Tribunal ............................ 126

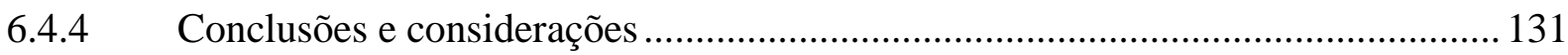

6.5 O Projeto de Lei $\mathbf{n}^{\mathbf{0}} \mathbf{1 0 . 2 2 0 / 2 0 1 8}$ para alteração da Lei $\mathbf{n}^{\mathbf{0}} \mathbf{1 1 . 1 0 1 / 2 0 0 5} \ldots \ldots \ldots . . . .132$

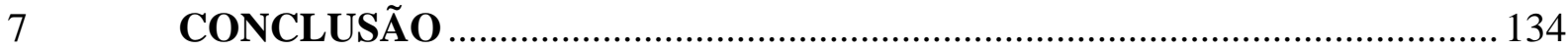

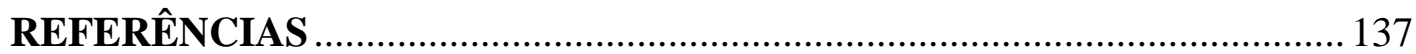





\section{INTRODUÇÃO}

\subsection{Tema a ser desenvolvido e suas limitações}

A dissertação de mestrado tem como título "Abuso do direito de voto afirmativo na Assembleia Geral de Credores" e pretende analisar a eventual existência de abuso do direito de voto em hipóteses em que credor ou grupo de credores com participação relevante aprova o plano de recuperação judicial.

O trabalho planeja desenvolver um paralelo entre a abordagem do abuso do direito do voto desfavorável ao plano e o tratamento do abuso do direito do voto afirmativo ${ }^{1}$, tanto pela doutrina quanto pela jurisprudência, para verificar se os parâmetros a serem aplicados para cada caso são e/ou podem ser similares.

O voto abusivo de credores que rejeitam o plano de recuperação judicial e a aprovação extraordinária prevista no artigo $58, \S 1^{\circ}$ e $\S 2^{\circ}$ da Lei $n^{\circ} 11.101 / 2005$ (cram down), bem como a produção literária sobre abuso do direito em assembleia geral de credores e a jurisprudência sobre voto abusivo em recuperações judiciais servirão como pilares para desenvolvimento da dissertação.

Além disso, embora não se negue a importância do voto dos credores na falência procedimento em que os credores têm competência para deliberar sobre métodos alternativos de liquidação dos ativos do devedor -, a deliberação a ser estudada nessa dissertação é a proferida no âmbito da Assembleia Geral de Credores que visa aprovar, rejeitar ou alterar o plano de recuperação judicial.

\subsection{Relevância do tema}

A Lei $\mathrm{n}^{\circ}$ 11.101, de 9 de fevereiro de $2005^{2}$, renovou os institutos aplicáveis às empresas em crise no Brasil e, ao adotar a chamada teoria da empresa, empenhou-se em regulamentar o sistema de insolvência em consonância com os ordenamentos estrangeiros e com os fundamentos norteadores do direito concursal moderno. ${ }^{3}$

1 A expressão "voto afirmativo" é utilizada no sentido de voto favorável à aprovação do plano de recuperação judicial.

2 O sistema concursal brasileiro era antes disciplinado pelo Decreto-Lei $n^{\circ} 7661 / 2005$ e previa os institutos da concordata e da falência.

3 Os termos direito concursal e direito da empresa em crise são utilizados sem distinção nesse trabalho, seguindo proposta apresentada por Sheila C. Neder Cerezetti que explica que "Os termos 'direito da empresa 
Nesse novo sistema de insolvência, foram introduzidos mecanismos destinados à salvação da empresa ${ }^{4}$ alternativamente à solução tradicional de liquidação e o credor, trilhando caminho diverso do modelo anterior $^{5}$, passou a exercer papel relevante nos procedimentos de recuperação extrajudicial e judicial, influenciando ativamente em seus resultados ${ }^{6}$.

Essa atribuição do credor costuma ser exercida, na maioria das oportunidades, mediante apresentação de objeção que, por consequência, provoca a convocação de Assembleia Geral de Credores, fórum de negociação coletiva destinado à verificação da viabilidade econômica da empresa e de seu plano de recuperação judicial.

A Lei $\mathrm{n}^{\circ} 11.101 / 2005$, contudo, muito embora tenha prestigiado a Assembleia Geral de Credores e o papel dos credores nesse processo de reorganização empresarial, não apresenta regra expressa sobre como o voto deve ser exercido pelos credores e ainda foi omissa ${ }^{7}$ a respeito da matéria de abuso do direito de voto ${ }^{8}$.

em crise' e 'direito concursal' são aqui utilizados indistintamente. A opção é feita muito embora se reconheça que o primeiro é mais moderno e alinhado com os instrumentos legais voltados a lidar com a crise empresarial, ao passo que o segundo tem sido superado devido ao viés limitador da expressão, que atenta mais para o concurso entre credores do que para a nova perspectiva de superação da crise e manutenção da organização empresarial que marca os institutos previstos na LRE." (NEDER CEREZETTI, Sheila C. Grupo de Sociedades e Recuperação Judicial. In: YARSHELL, Flávio Luiz; PEREIRA, Guilherme Setoguti J. (coord). Processo Societário. São Paulo, Quartier Latin, 2005. v. II, p. 736)

4 Importante esclarecer que a jurisprudência, mesmo quando da vigência do Decreto Lei no $7661 / 45$, já se alinhava no sentido de aplicar o princípio da preservação da empresa e a Lei $\mathrm{n}^{\circ} 11.101 / 2005$ apenas teria proporcionado a positivação da evolução jurisprudencial. Nesse sentido, v. GARDINI, Adriana Valéria Pugliesi. A evolução do Tratamento Jurídico da Empresa em Crise no Direito Brasileiro. Dissertação (Mestrado) - Faculdade de Direito da USP, São Paulo, 2006.

5 O sistema falimentar brasileiro, observou Fabio Konder Comparato, manteve um ritmo pendular, pois a legislação ora protege devedor, ora protege credores (COMPARATO, Fabio Konder. Aspectos jurídicos da macroempresa. São Paulo: RT, 1970. p. 98-101). Esse ritmo pendular, ainda, pode também ser verificado em relação ao poder do juiz versus o poder atribuído aos credores no sistema falimentar.

6 No Decreto-Lei $n^{\circ} 7.661 / 45$, os artigos 122 e 123 previam a deliberação por credores, muito embora com um papel diverso ao contido na Lei $\mathrm{n}^{\circ} 11.101 / 2005$.

7 As omissões legislativas podem ser intencionais ou não intencionais, conforme Tércio Sampaio Ferraz Jr.: "O critério diferenciador está na vontade daquele que elabora o plano e que pode, conscientemente ou não, deixar uma questão em aberto. No primeiro caso, o legislador, por não se julgar em condições, atribui a outra pessoa (ao juiz, à doutrina) a tarefa de encontrar a regra específica. No segundo, diz-se que o legislador não chegou a perceber a problemática da questão de modo cabal (lacuna de previsão), seja porque as condições históricas não o permitiam (lacunas desculpáveis), seja porque seu exame do problema não foi suficientemente cuidadoso (lacunas não-desculpáveis)." (FERRAZ JR, Tércio Sampaio. Introdução ao estudo do Direito: técnica, decisão, dominação, 2. ed. São Paulo: Atlas, 1994, p. 220)

No mesmo sentido: BOBBIO, Norberto. Teoria Geral do Direito. 3. ed. São Paulo: Martins Fontes, 2010. p. 297.

8 Nesse sentido, Erasmo Valladão Azevedo e Novaes França aponta: "Uma das hipóteses mais comuns de vício de voto é o voto proferido em conflito de interesses. Sucede que, em franco descompasso com a Lei das S/A (artigo $115, \S 4^{\circ}$ ), o Código Civil, subsidiariamente aplicável à Lei $n^{\circ} 11.101$, não prevê a anulação das deliberações tomadas em decorrência de voto conflitante. A Lei $n^{\circ} 11.101$, infelizmente, não trata da matéria.” (FRANÇA, Erasmo Valladão Azevedo e Novaes. A Assembleia de Credores na Nova Lei 
A omissão contida na Lei $\mathrm{n}^{\circ} 11.101 / 2005$ sobre a matéria exigiu que o intérprete aplicasse subsidiariamente o Código $\mathrm{Civil}^{9}$ que, no artigo $187^{10}$, estabelece que um direito será abusivamente exercido quando extrapolar o seu fim econômico ou social, os limites da boa-fé ou dos bons costumes.

A apuração de abuso do direito de voto na recuperação judicial, assim, exigirá preliminarmente a identificação do interesse social ou interesse recuperacional, o que não é tarefa fácil ${ }^{11}$ e passará pela investigação dos limites da autonomia dos credores e da interferência jurisdicional dentro do sistema concursal. A grande questão a ser respondida é se os credores poderiam votar exclusivamente em conformidade com seu interesse econômico e patrimonial ou se deveriam orientar seu voto para também contribuir com a salvação da atividade empresarial viável (propósito declarado no artigo 47 da Lei nº11.101/2005).

A omissão da Lei de Recuperação de Empresas e Falências a respeito dos limites do exercício do voto credor em contraposição ao papel relevante atribuído ao credor sobre a análise da viabilidade econômica da empresa em crise, por si só, justifica a relevância do tema. Ocorre que o abuso do direito do voto tem sido mais debatido por doutrina e jurisprudência quando o interesse patrimonial do credor se contrapõe à manutenção da atividade empresarial do devedor, isto é, quando o credor rejeita o plano. ${ }^{12}$

Essa dissertação, no entanto, pretende analisar o abuso do direito do credor sobre a perspectiva oposta, isto é, averiguar se é possível afirmar a existência de abuso do voto favorável à aprovação do plano e se a questão é enfrentada da forma necessária pela doutrina e pelos Tribunais.

Isso porque, decorridos mais de 13 anos da vigência da Lei n ${ }^{\circ} 11.101 / 2005$, os planos de recuperação judicial apresentam-se mais complexos e bem elaborados e, não raras vezes,

Falimentar. In: Temas de Direito Societário, Falimentar e Teoria da Empresa. 1. ed. São Paulo: Malheiros, 2009. p. 21)

9 MUNHOZ, Eduardo Secchi. Anotações sobre os limites do poder jurisdicional na apreciação do plano de recuperação judicial. Revista de Direito Bancário e do Mercado de Capitais, v. 10, n. 36, p. 184-199, abr./jun. 2007., p. 301 e;.DE LUCCA, Newton. Abuso do Direito de Voto do Credor na Assembleia Geral de Credores prevista nos arts. 35 a 46 da Lei $n^{\circ}$ 11.101/2005. In: DE LUCCA, Newton; DOMINGUES, Alessandra de Azevedo; ANTONIO Nilva M. Leonardi. Direito Recuperacional II: Aspectos Teóricos e Práticos, São Paulo: Quatier Latin, 2012, p. 228.

10 Artigo 187. Também comete ato ilícito o titular de um direito que, ao exercê-lo, excede manifestamente os limites impostos pelo seu fim econômico ou social, pela boa-fé ou pelos bons costumes.

11 Conforme: FRANÇA, Erasmo Valladão Azevedo e Novaes. Temas de Direito Societário, Falimentar e Teoria da Empresa. 1. ed. São Paulo: Malheiros, 2009.

12 Nesse sentido: MARIANO, Álvaro Augusto Camilo. Abuso de voto na recuperação judicial. Tese (Doutorado) -Faculdade de Direito da Universidade de São Paulo, São Paulo, 2012.

BUSCHINELLI, Gabriel Saad Kik. Abuso do Direito de Voto na Assembleia Geral de Credores. São Paulo: Quartier Latin, 2014. e capítulo 6.4 dessa dissertação sobre aplicação pela jurisprudência. 
preveem a figura do credor estratégico ou colaborador, envolvem tratativas preliminares, além de estruturas de cessão de crédito que poderão ser utilizados como instrumento para obtenção do quórum legal e consequente aprovação do plano.

Assim, o abuso do voto afirmativo no âmbito do procedimento de recuperação judicial, ainda que possivelmente menos frequente ou menos provocado perante o Poder Judiciário em comparação com o abuso do direito de voto desfavorável ao plano, parece existir e o fato de ser menos numeroso justifica a inquietação pelo tema.

Esse limite ao exercício do direito do voto do credor, caso exista, deve ser observado não apenas em relação ao voto que rejeita ao plano, mas também com relação ao voto que aprova o plano de recuperação, sob pena de contribuir para alocação equivocada de recursos e para a deterioração do ativo da empresa, em violação aos propósitos na atual legislação de insolvência.

O aprofundamento da pesquisa pretende investigar se o credor, ao exercer seu direito de voto afirmativo e apreciar o plano de recuperação judicial, deve não apenas atender seu interesse econômico exclusivo, mas também tem o dever de analisar de forma comprometida a viabilidade da atividade empresarial e a possibilidade de salvamento da empresa.

\subsection{Problema e hipótese preliminar}

O problema de pesquisa que norteará a dissertação a ser desenvolvida pode ser apresentado por meio das seguintes perguntas: Em que medida um voto favorável à aprovação do plano de recuperação judicial pode ser considerado abusivo? E, caso seja possível, os votos afirmativos e os votos desfavoráveis ao plano são ou devem ser tratados com simetria pela doutrina e jurisprudência?

A hipótese preliminar, tendo em vista o problema acima apontado, é que (i) existem situações de abuso do direito de voto favorável à aprovação do plano de recuperação judicial e (ii) o voto afirmativo não é investigado pela doutrina e jurisprudência com a mesma recorrência que o voto desfavorável ao plano.

\subsection{Estrutura do Trabalho}

Capítulo 1. Introdução - Nesse capítulo, será apresentado o tema, a justificativa de sua escolha, a estrutura do trabalho e a metodologia a ser aplicada. 
Capítulo 2. Abuso do direito - Esse capítulo será dedicado a estudar o instituto do abuso do direito e a buscar parâmetros para diferenciar o abuso do direito do exercício regular do direito com enfoque no tratamento do tema pela doutrina estrangeira - em especial, francesa e portuguesa.

O capítulo pretende ainda tecer considerações sobre (i) o artigo 187 do Código Civil e (ii) o artigo 115 da Lei de Sociedades Anônimas para verificar em que extensão a experiência relacionada às assembleias societárias podem e devem ser aplicadas por analogia, tendo em vista omissão sobre a matéria na Lei $\mathrm{n}^{\circ} 11.101 / 2005$.

Capítulo 3. Os interesses envolvidos no processo de recuperação judicial - A terceira parte analisará os interesses tutelados pelo processo de reorganização, reconhecendo o interesse do devedor, o interesse comum dos credores e analisando a existência de outros interesses envolvidos ou a serem tutelados. Além disso, o capítulo buscará abordar qual o propósito almejado pelo sistema de insolvência moderno.

Capítulo 4. O papel dos credores na recuperação judicial - Nesse capítulo, pretende-se apresentar a dinâmica da Assembleia Geral de Credores e os aspectos da negociação coletiva entre credores e devedor. Também é abordado o papel atribuído aos credores dentro do processo de recuperação e, delineado esse papel, intenta analisar se o voto do credor poderá atender apenas seus interesses patrimoniais ou se ele deverá ser exercido amparado pelos fins sociais do processo de reorganização da empresa.

Capítulo 5. Os limites da atuação jurisdicional sobre o exercício do voto do credor - O quinto capítulo se destina a pesquisar os limites da atuação jurisdicional no nosso ordenamento jurídico, analisando quais os parâmetros são utilizados pelos ordenamentos estrangeiros.

O capítulo ainda projeta apurar em que medida a interferência do Poder Judiciário na relação entre devedor e credores, com reconhecimento de votos abusivos e afastamento da vontade da maioria, será necessária para atingir equilíbrio e composição dos diversos interesses tutelados pelo sistema concursal e para impedir comportamentos oportunistas.

Capítulo 6. Abuso do Direito de Voto na Recuperação Judicial - Por fim, o último capítulo discorrerá sobre o abuso do direito de voto na recuperação judicial e identificará a existência de parâmetros apontados pela doutrina nacional e estrangeira. Busca-se compreender se é possível identificar vetores para reconhecimento do voto abusivo que veta o plano de recuperação judicial.

Esse capítulo é o cerne da dissertação e pretende identificar algumas hipóteses - não exaustivas - de situações que podem configurar abuso do voto afirmativo, estabelecendo um 
paralelo com os parâmetros encontrados em relação ao voto desfavorável ao plano de recuperação.

Por fim, o capítulo se dedicará também a apresentar a coleta de jurisprudência e análise dos parâmetros estabelecidos pelo Tribunal de Justiça do Estado de São Paulo para aferição do abuso do direito de voto, tanto negativo quanto afirmativo. Pretende-se demonstrar que a discussão de abuso do voto afirmativo é menos discutida que o voto desfavorável ao plano e que os parâmetros estabelecidos para aferição do voto afirmativo e negativo não são exatamente os mesmos.

Capítulo 7. Conclusão - Nesse capítulo, será apresentada a síntese dos resultados alcançados ao longo da dissertação e as considerações finais.

\subsection{Metodologia}

O desenvolvimento da pesquisa terá suporte nos seguintes métodos de investigação:

\subsubsection{Revisão bibliográfica:}

Análise e discussão das posições doutrinárias nacionais e estrangeiras sobre o abuso do direito, os interesses envolvidos no sistema de insolvência e o abuso do direito de voto do credor.

O levantamento bibliográfico inicial foi realizado por meio de pesquisa pautada em palavras-chave como abuso do direito, voto, credores, recuperação judicial e Assembleia Geral de Credores e, após a identificação das principais obras, iniciou-se a revisão bibliográfica pelas obras mais recentes e por aquelas que já haviam sido mencionadas por outros autores em referências cruzadas ou reiteradas, indicando indícios de relevância do material para o estudo do tema. ${ }^{13}$

$\mathrm{Na}$ revisão bibliográfica, além da doutrina nacional, foram analisadas doutrinas portuguesa e francesa a respeito da matéria de abuso do direito pelas referências reiteradas. Em relação aos aspectos envolvendo o direito da empresa em crise, abordou-se as doutrinas

${ }^{13}$ Eduardo C. Silveira Marchi esclarece que a identificação das chamadas "leituras de base", consideradas essenciais e mais relevantes, "basear-se-á no chamado método do controle cruzado, automaticamente derivado daquelas etapas de procura: as obras mais citadas por todos, ou pela maioria, serão os principais estudos a serem levados em consideração pelo pesquisador. Uma vez identificadas essas leituras de base, o critério seguinte, para determinar a ordem de leitura entre elas, será o da novidade: deve-se começar pela obra mais recente." (MARCHI, Eduardo C. Silveira. Guia de Metodologia Jurídica. São Paulo: Saraiva, 2009. p. 145-146) 
(i) norte-americana, pela influência exercida sobre o nosso sistema de insolvência vigente e (ii) alemã, portuguesa e francesa pelas referências reiteradas nas obras consultadas.

Assim, torna-se importante esclarecer que a revisão bibliográfica apontada não tem cunho comparatístico, mas sim de exploração da experiência de outros ordenamentos, tendo como objetivo tão somente encontrar e apresentar contribuições positivas às interpretações da lei e às propostas ao tema. ${ }^{14}$

\subsubsection{Coleta de jurisprudência:}

Diante da ausência de normatização específica sobre a matéria de abuso do direito do voto no nosso sistema concursal, a pesquisa jurisprudencial foi realizada com o objetivo de apurar se as decisões proferidas pelo Tribunal de Justiça de São Paulo ${ }^{15}$ estabelecem os parâmetros necessários para promover segurança e previsibilidade para credores, devedores e todos os demais interessados no procedimento concursal.

Além disso, ao longo da elaboração da dissertação, a jurisprudência norte-americana, limitada às decisões citadas pela doutrina analisada, foi revisitada para fins de investigar a tendência dos julgados acerca do tratamento do abuso do direito nas deliberações no âmbito da Assembleia Geral de Credores em procedimentos de reorganização empresarial naquele ordenamento.

\subsubsection{Análise econômica do Direito $^{16}$}

A análise dos votos abusivos foi realizada à luz dos interesses envolvidos no processo de reorganização da empresa com o objetivo de contribuir com um processo eficiente,

\footnotetext{
14 "Direito Comparado é ciência (ou método) que estuda por meio de contrastes, dois ou mais sistemas jurídicos, analisando suas normas positivas, suas fontes, sua história e os variados fatores sociais e políticos que os influenciam." (DOLINGER, Jacob. Direito Internacional Privado: parte geral. 5. ed. Rio de Janeiro: Renovar, 1997. p. 27)

${ }^{15}$ A pesquisa pretende analisar precedentes do Tribunal de Justiça de São Paulo (TJSP), desde o início da vigência da Lei $\mathrm{n}^{\circ} 11.101 \mathrm{em} 2005$ até as decisões proferidas em junho de 208. O TJSP foi escolhido por representar, em conjunto com o Tribunal de Justiça do Rio de Janeiro, mais de $70 \%$ dos julgamentos envolvendo a Lei $\mathrm{n}^{\circ}$ 11.101/2005 até o ano de 2011, segundo estudo encomendado pela Secretaria de Assuntos Legislativos do Ministério da Justiça à Fundação Getúlio Vargas, in <http://pensando.mj.gov.br/publicacoes/?filter-name=fal\%C3\%AAncia〉, acesso em 1.7.2016.

16 Não são desconhecidas as limitações sobre o método Análise Econômica do Direito. Nesse sentido: FORGIONI, Paula Andrea. Análise econômica do Direito: paranoia ou mistificação? Revista do TRF - $3^{\mathrm{a}}$ Região, 77. p. 35-61.
} 
promover o incentivo a investimentos e a participação efetiva dos credores e estimular a preservação da função social da empresa. ${ }^{17}$

Nesse sentido, partindo da premissa de que a Assembleia Geral de Credores é um instrumento de negociação coletiva ${ }^{18}$, a busca de eficiência ${ }^{19}$ foi orientada pelas considerações do contrato como viabilizador da circulação de riquezas, cujas principais funções seriam: prevenir o oportunismo, apresentar cláusulas eficientes, alocar os riscos de forma eficiente e, ainda, reduzir os custos de transação.

\subsubsection{Método indutivo}

Com base na observação de casos concretos coletados na jurisprudência e nas discussões extraídas da revisão bibliográfica, elaborou-se uma proposta para solução das questões apresentadas.

17 Nesse sentido Calixto Salomão Filho, ao comentar a atual lei de insolvência, destaca a importância dos efeitos sistêmicos decorrentes de uma lei eficiente: "No caso da existência de um processo de recuperação de empresas eficaz e célere, o estímulo será a maior assunção de riscos ou o maior nível de investimentos por parte da empresa, por ser menos grave e, sobretudo, por não ser mais irreversível o processo de ruína do empreendimento" (In: PITOMBO, Antônio Sérgio A. de Moraes; SOUZA JÚNIOR, Francisco Satiro de (Org.). Comentários à Lei de Recuperação de empresa e falência. 2. ed. São Paulo: Revista dos Tribunais, 2008. p. 54)

18 "Poder-se-á dizer que o plano é um negócio de cooperação celebrado entre devedor e credores, homologado pelo juiz. No que diz respeito ao negócio de cooperação, assemelha-se ao contrato plurilateral; no que diz respeito à homologação, pode-se considerar forma de garantia do cumprimento das obrigações assumidas, com o que reduzem os custos de transação dada a coercitividade que dela, homologação, resulta." (FRANCO, Vera Helena de Mello; SZTAJN, Rachel. Falência e recuperação da empresa em crise (comparação com as posições do direito europeu). 1. ed. Rio de Janeiro: Campus Elsevier, 2008. p. 234)

19 POSNER, Richard A. Economic Analisys of Law. 7. ed. New York: Aspen Publishers, 2007. p. 108. 


\section{CONCLUSÃO}

Esta dissertação visou a estudar o abuso do voto favorável ao plano de recuperação judicial e a possibilidade de o juiz caracterizada essa hipótese, não aprovar o plano do devedor que obteve a maioria legal necessária em todas as classes. $\mathrm{O}$ estudo almejou ainda investigar (i) a existência de situações de abuso do direito de voto favorável ao plano de recuperação judicial e (ii) se há tratamento simétrico para as hipóteses de abuso do voto desfavorável ao plano de recuperação judicial em comparação com o abuso do voto afirmativo.

Inicialmente, foram delineadas as noções gerais da teoria do abuso do direito, com enfoque no dispositivo contido no Código Civil e em sua extensão e a matéria de abuso do voto na lei acionária, as quais contribuíram para a compreensão do assunto e estabelecer parâmetros para diferenciar o abuso do direito do seu exercício regular, sobretudo em razão da verificação da lacuna sobre a matéria de abuso do direito de voto e suas implicações em nosso sistema concursal e da necessidade de aplicação subsidiária dos institutos.

Em seguida, passou-se a abordar os interesses tutelados pelo direito concursal moderno, o papel conferido aos credores dentro desse novo sistema e os limitesda interferência jurisdicional sobre as deliberações assembleares, com o propósito de apurar se o conjunto de normas constantes na Lei $n^{\circ}$ 11.101/2005 está orientado para a harmonização da ampla gama de interesses afetados pela empresa em crise.

Recorreu-se, ainda, aos ordenamentos estrangeiros para compreensão das soluções adotadas sobre a matéria e constatou-se que o nosso ordenamento jurídico não estabelece critérios para a atuação do juiz sobre a manifestação individual do credor e não contém mecanismo de proteção aos credores dissidentes à aprovação do plano.

Recorreu-se, aos ordenamentos estrangeiros para investigação de mecanismos legais para superação da vontade assemblear pelo juiz e compreensão das soluções adotadas sobre a matéria de abuso do direito de voto em processo de reorganização. Constatou-se que o nosso ordenamento jurídico não contém mecanismo de proteção aos credores dissidentes à aprovação do plano e não estabelece critérios adequados para a atuação do juiz sobre a manifestação individual do credor, afastando das diretrizes estabelecidas pelos demais ordenamentos.

Posteriormente, identificou-se cenários, não exaustivos, em que o voto favorável ao plano poderá ser considerado abusivo por ser utilizado pelo credor para atingir vantagem 
indevida ou fraudar a formação da maioria, extrapolando os fins econômicos, sociais, boa-fé ou bons costumes.

Por fim, foi realizada análise do repertório de decisões do Tribunal de Justiça de São Paulo para identificar possíveis vetores para reconhecimento do exercício abusivo do direito de voto e como a abusividade dos votos proferidos pelos credores, desfavoráveis ou favoráveis ao plano, tem sido debatida na jurisprudência.

Após o término da pesquisa, podem ser extraídas as seguintes conclusões:

1. A Lei $\mathrm{n}^{\circ} 11.101 / 2005$ atribuiu aos credores papel relevante dentro do processo de recuperação judicial porque, em última análise, são responsáveis pela decisão sobre a recuperabilidade ou não do devedor.

2. Ao exercerem seus direitos de voto para concordar ou não com o plano proposto pelo devedor, os credores detêm o poder de intervir na esfera de direitos do devedor e de outros credores, diante da força vinculativa das decisões assembleares, bem como dos múltiplos interesses envolvidos com a empresa em crise, que serão afetados pelo resultado anunciado.

3. A tutela da preservação da atividade empresária em crise e da vasta gama de interesses envolvidos com empresa devedora, sugere uma relativização do papel atribuído aos credores e da autonomia da vontade manifestada por eles.

4. A regularidade do exercício do direito de voto se fundamentará na inexistência de transgressão manifesta dos seus fins econômicos ou sociais, da boa-fé e dos bons costumes, por aplicação do artigo 187 do Código Civil.

5. Os propósitos declarados pelo artigo 47 da Lei $\mathrm{n}^{\circ}$ 11.101/2005 não podem exclusivamente serem utilizados para desqualificar o voto do credor que rejeita o plano ou considerá-lo abusivo.

6. A efetivação dos propósitos declarados no artigo 47 da Lei no 11.101/2005 dependerá da existência de regras procedimentais que assegurem a integração e o equilíbrio entre os múltiplos interesses envolvidos na reorganização da atividade empresarial.

7. O sistema concursal brasileiro, afastando-se das diretrizes encontradas em outros ordenamentos jurídicos, não goza de instrumentos que autorizem a intervenção jurisdicional quando o quórum do artigo 45 da Lei $n^{\circ}$ 11.101/2005 é atingido e o plano é aprovado por todas as maiorias legalmente exigidas.

8. O estudo dos modelos estrangeiros revela ainda que o nosso ordenamento não contém mecanismo de proteção aos credores dissidentes ao plano e não se preocupou em fixar critérios efetivos para atuação judicial em busca da harmonização de todos interesses envolvidos no processo de recuperação. 
9. É possível identificar hipóteses em que o voto afirmativo ao plano poderá ser abusivo, com base nas experiências estrangeiras, mas os votos abusivos afirmativos ao plano não são debatidos com a mesma recorrência que os votos desfavoráveis ao plano e tampouco são reconhecidos pela jurisprudência.

10. A ausência de instrumentos que autorizem a intervenção jurisdicional quando o plano é aprovado e de ferramentas de proteção aos credores dissidentes parecem ser as razões da assimetria de tratamento entre as hipóteses de abuso afirmativo e do voto desfavorável ao plano, sugerindo a necessidade de alterações legislativas. 


\section{REFERÊNCIAS $^{434}$}

ABRÃO, Nelson. O Novo Direito Falimentar: nova disciplina jurídica da crise econômica da empresa. São Paulo: Revista dos Tribunais, 1985.

Da Caracterização da Falência. São Paulo: Revista dos Tribunais, 1970.

ADAMEK, Marcelo Vieira von, Abuso de minoria em direito societário. São Paulo: Malheiros, 2014.

(coord.), Temas de Direito Societário e Empresarial Contemporâneos. São Paulo:

Malheiros, 2011.

ABREU, Jorge Manoel Coutinho. Do abuso de direito. Coimbra: Almedina, 2006.

AGUIAR JÚNIOR, Ruy Rosado de. Projeto do Código Civil: As Obrigações e os Contratos. Revista dos Tribunais, São Paulo, n. 775, p. 18-31, maio 2000.

ALEIXO, Ana Paula. A cessão de crédito na recuperação judicial. Dissertação (Mestrado) Faculdade de Direito da Universidade de São Paulo, São Paulo, 2018.

ANDRADE, Jorge Pereira. Manual de Falências e Concordatas. 5. ed. São Paulo: Atlas, 1996.

ASCARELLI, Tullio, Problemas das Sociedades Anônimas e Direito Comparado. São Paulo: Saraiva, 1969.

AYOUB, Luiz Roberto; CAVALLI, Cassio, A construção jurisprudencial da Recuperação Judicial de Empresas. Rio de Janeiro: Forense, 2013.

BAIRD, Douglas. Elements of Bankruptcy. 6. ed. St. Paul: Foundation Press, 2014.

G. Loss Distribution, Forum Shopping, and Bankruptcy: A Reply to Warren. University of Chicago Law Review. v. 54, p. 815-834, 1987.

BAIRD, Douglas G. RASMUSSEN, Robert K. Control Rights, Priority Rights, and the Conceptual Foundations of Corporate Reorganizations. Va. L. Rev., v. 87, p. 921-959, 2001.

The End of Bankruptcy. Stan. L. Rev., v. 55, p. 751-789, 2002-2003.

${ }^{434}$ De acordo com a Associação Brasileira de Normas Técnicas (ABNT NBR 6023) 
BAIRD, Douglas G.; JACKSON, Thomas H. Corporate Reorganizations and the Treatment of Diverse Ownership Interests: A Comment on Adequate Protection of Secured Creditors in Bankruptcy. University of Chicago Law Review, v. 97, p. 97-130, 1984.

BALZ, Manfred. Market Conformity of Insolvency Proceedings: Policy issues of the German Insolvency Law. Brook. J. Int'l L., v. 23, p. 167-179, 1997.

BERGER, Dora. A Insolvência no Brasil e na Alemanha. Porto Alegre: Sergio Antonio Fabris Editor, 2001.

BESSONE, Darcy. Do Contrato: teoria geral. 4. ed. São Paulo: Saraiva, 1997.

BEZERRA FILHO, Manoel Justino. Nova Lei Recuperação e Falências comentada. 3. ed. São Paulo: Revista dos Tribunais, 2005.

BEVILAQUA, Clovis. Código Civil dos Estados Unidos do Brasil. 11. ed. atual. São Paulo: Livraria Francisco Alves, 1956.

BESSONE, Darcy Do contrato: teoria geral. São Paulo: Forense, 1987.

BLOCK-LIEB, Susan. The Logic and Limits of Contract Bankruptcy. University of Illinois Law Review, v. 503, p. 503-560, 2001.

BOBBIO, Norberto, Teoria Geral do Direito. 3. ed. São Paulo: Martins Fontes, 2010.

BORBA, José Edwaldo Tavares, Direito Societário. 9. ed. rev. aum. e atual. Rio de Janeiro: Renovar, 2004.

BOULOS, Daniel M. Abuso do Direito no novo código civil. São Paulo: Método, 2006.

BRADLEY, Michael; ROSENZWEIG, Michael. The untenable case for Chapter 11. Yale Law Journal, v. 101, p. 1.043-1.095, 1992.

BULGARELLI, Waldirio. Apontamentos sobre a responsabilidade dos administradores das companhias. Revista de Direito Mercantil, Industrial, Econômico e Financeiro, n.50, p. 75$105,1983$.

. Regime Jurídico da Proteção às Minorias nas S/A. Rio de Janeiro: Renovar, 1998.

BULHÕES PEREIRA, José Luiz; LAMY FILHO, Alfredo. A Lei das S.A. 2. ed. Rio de Janeiro: Renovar, 1992.

BUSCHINELlI, Gabriel Saad Kik. Abuso do Direito de Voto na Assembleia Geral de Credores. São Paulo: Quartier Latin, 2014. 
CAMPANA FILHO, Paulo Fernando; BATISTA, Carolina Soares João; NEDER CEREZETTI, Sheila Christina; MIYAZAKI, Renata Yumi, A prevalência da vontade da assembleia-geral de credores em questão: o cram-down e a apreciação do plano por todas as classes. São Paulo: Malheiros, 2006.

CAMPOS FILHO, Moacyr Lobato de. Falência e Recuperação Judicial. Belo Horizonte: Editora Del Rey, 2007.

CARPENA, Heloisa. Abuso do Direito no Código Civil de 2002. Relativização dos Direitos na ótica civil-constitucional. In: TEPEDINO, Gustavo (coord.). A Parte Geral no novo código civil: estudos na perspectiva civil-constitucional, Rio de Janeiro: Renovar, 2002.

CARVALHOSA, Modesto. Comentários à Lei de sociedades anônimas. vol 1-4. São Paulo: Saraiva, 2014.

; EIZIRIK, Nelson. A nova Lei das Sociedades Anônimas. São Paulo: Saraiva, 2002.

CASTRO, Rodrigo Rocha Monteiro de; WARDE JR, Walfrido Jorge; GUERREIRO, Carolina Dias Tavares. Direito Empresarial e Outros Estudos em Homenagem ao Professor José Alexandre Tavares Guerreiro. São Paulo: Quartier Latin, 2013.

COELHO, Fábio Ulhoa. Comentários à Nova Lei de Falências e Recuperação de Empresas. São Paulo: Saraiva, 2005.

Curso Direito Comercial. São Paulo: Saraiva, 2012.

COMPARATO, Fabio Konder, Aspectos jurídicos da macroempresa. São Paulo: RT, 1970.

. Direito Empresarial: Estudos e Pareceres. São Paulo: Saraiva, 1990.

Perfis da Empresa. Revista de Direito Mercantil, Industrial Econômico e Financeiro. São Paulo, n. 104, p. 109-126, out./dez. 1996.

. Seguro do Crédito. São Paulo: RT, 1968.

Poder de Controle. 3. ed. rev. atual. e corr., Rio de Janeiro: Forense, 1983.

.; SALOMÃO FILHO, Calixto. O poder de controle na sociedade anônima. 6. ed. rev. e atual. Rio de Janeiro: Forense, 2014.

COOTER, Robert; ULEN, Thomas. Direito e economia. 5. ed. Porto Alegre: Bookman, 2010.

CORREIA Luís Brito. Os Administradores de sociedade anônimas. Coimbra: Almedina, 1993. 
CUNHA DE SÁ, Fernando Augusto. Abuso do Direito. Coimbra: Almedina, 2005.

DANIEL, Eduardo Carestiano. A Teoria do abuso do direito e sua aplicabilidade no direito tributário. Cadernos de Direito Tributário e Finanças Públicas, v. 6, n. 24, p. 11-43, jul./set. 1998.

DE LUCCA, Newton; SIMÃO FILHO, Adalberto (coord.). Comentários à Nova Lei de Recuperação de Empresas e Falências. São Paulo: Quartier Latin, 2005.

; VASCONCELOS, Miguel Pestana de (coord.), Falência, Insolvência $e$ Recuperação de Empresas: estudos luso-brasileiros. São Paulo: Quartier Latin, 2015.

DE LUCCA, Newton; DOMINGUES, Alessandra de Azevedo (coord.), Direito Recuperacional: aspectos Teóricos e Práticos. São Paulo: Quartier Latin, 2009.

; ANTONIO Nilva M. Leonardi (coord.). Direito Recuperacional II: Aspectos Teóricos e Práticos, São Paulo: Quatier Latin, 2012.

DE MORAES, Luiza Rangel. Recuperação Judicial de Empresas e o Mercado de Valores Mobiliários. Revista de Direito Bancário, São Paulo, p. 32-62, jan./mar. 2006.

DEZEM, Renata Mota Maciel. A Universalidade do Juízo da Recuperação Judicial. São Paulo: Quartier Latin, 2017.

DIAS, Leonardi Adriano Ribeiro. Financiamento na Recuperação Judicial e na Falência. São Paulo: Quartier Latin, 2014.

DOLINGER, Jacob. Direito Internacional Privado: parte geral. 5. ed. Rio de Janeiro: Renovar, 1997.

EIZIRIK, Nelson, A Lei das S/A Comentada: Arts. 121a 188. v. 2. São Paulo: Quartier Latin, 2011.

ELIAS, Luis Vasco (coord.). 10 anos da Lei de Recuperação de Empresas e Falência: reflexões sobre a reestruturação empresarial. São Paulo: Quartier Latin, 2015.

FERRAZ JR., Tercio Sampaio. Introdução ao estudo do Direito: técnica, decisão, dominação. 2. ed. São Paulo: Altas 1994.

FLESSNER, Axel. Philosophies of Business Bankruptcy Law: An International Overview. In: ZIEGEL, Jacob S. (org.), Current Developments in International and Comparative Corporate Insolvency Law.Oxford: Clarendon, 1994. p. 19-28.

FORGIONI, Paula Andrea. Análise econômica do Direito: paranoia ou mistificação? Revista do TRF - 3 ${ }^{\text {a }}$ Região, n. 77, p. 35-61, maio/jun. 2006. 
FRANÇA, Rubens Limongi. Responsabilidade civil e abuso de direito. Revista do Advogado, São Paulo, n. 19, p. 40-45, out. 1985.

FRANÇA, Erasmo Valladão Novaes e. Temas de Direito Societário, Falimentar e Teoria da Empresa. 1. ed. São Paulo: Malheiros, 2009.

Conflito de interesses nas assembleias de S.A. 2. ed. São Paulo: Malheiros, 2014.

Invalidade das deliberações de assembleias das S/A. 2. ed. rev. e aum., São Paulo: Malheiros, 2017.

FRANCO, Vera Helena de Mello. A crise econômica e a reforma do direito concursal no continente europeu: função social ou manutenção da sociedade? RT, v. 936, p. 73, 2013.

FRANCO, Vera Helena de Mello; SZTAJN, Rachel, Falência e recuperação da empresa em crise (comparação com as posições do direito europeu). 1. ed. Rio de Janeiro: Campus Elsevier, 2008.

FROST, Christopher W. Bankruptcy Redistributive Policies and the Limits of the Judicial Process. N. C. L. Rev., v. 74, p. 75-139, 1995.

GARDINI, Adriana Valeria Pugliesi. A evolução do Tratamento Jurídico da Empresa em Crise no Direito Brasileiro, Dissertação (Mestrado) - Faculdade de Direito da Universidade de São Paulo, São Paulo, 2006.

GOMES, Orlando. Contratos. Rio de Janeiro: Forense, 2007.

Introdução ao Direito Civil. 21. ed. rev. e atual. Rio de Janeiro: Forense, 2016.

GONÇALVES, Luiz da Cunha, Princípios de Direito Civil Luso-Brasileiro. São Paulo: Max Limonad, 1951.

GROSS, Karen, Failure and Forgiveness: Rebalancing the Bankruptcy system. New Haven: Yale University Press, 1997.

GUSMÃO, Paulo Dourado. O abuso do direito. Revista Forense, Rio de Janeiro, n. 118, p. 359-371, ago.1948.

Pressupostos filosóficos da noção do abuso do direito. Revista Forense, Rio de Janeiro, n. 120, p. 372-378, dez. 1948.

GUERRA, Alexandre. Responsabilidade Civil por Abuso de Direito. São Paulo: Saraiva, 2011.

HANSMANN, Henry; KRAAKMAN, Reinier. The end history for corporate law. The Georgetown Law Journal, v. 89 , p. 439-468, 2001. 
HART, Oliver. Differents Approaches to Bankruptcy. Cambridge, sep. 2000.

JACKSON, Thomas H. Of liquidation, continuation, and delay: an analysis of bankruptcy and nonbankruptcy rules. American Bankruptcy Law Journal, v. 60, p. 399-428, 1986.

JOSSERAND, Louis. De l'espirit des sroits et de leur relativité: Théorie dite de labus des droits. 2. ed. Paris: Dalloz, 1939.

KOROBKIN, Donald R. Rehabilitating values: a jurisprudence of bankruptcy. Columbia Law Review, v. 91, p. 717-789, 1991.

LAUTENCSCHLAGER, Milton Flávio de Almeida Camargo. Abuso do Direito. São Paulo: Atlas, 2007.

LEÃES, Luis Gastão Paes de Barros. Conflito de Interesses. In: Estudos e Pareceres sobre sociedades anônimas. São Paulo: Revista dos Tribunais, p. 9-27, 1989.

LEVADA, Cláudio Antônio Soares. Anotações sobre o Abuso de Direito. Revista dos Tribunais, São Paulo, ano 80, n. 667, maio 1991.

LIMA, Alvino. Culpa e Risco. 2. ed. rev. e atual. São Paulo: Revista dos Tribunais, 1988.

LOBO, Jorge. Direito Concursal. 3. ed. Rio de Janeiro: Forense, 1999.

. Direito da Crise Econômica da Empresa. Revista de Direito Mercantil, Industrial Econômico e Financeiro, São Paulo, n. 109, p. 64-92, jan./mar. 1998.

LOBO, Jorge; PIMENTEL, Sérgio. A Recuperação da Empresa em Crise no Direito Francês. Revista de Direito Mercantil, Industrial Econômico e Financeiro. São Paulo, n.113, p. 148153, jan./mar. 1999.

LOPUCKI, Lynn. The Nature of the Bankrupt Firm: A Response to Baird and Rasmussen's The End of Bankruptcy. Stan. L. Rev., v. 56, p. 645-671, 2003.

A Team Production Theory of Bankruptcy Reorganization. Vanderbilt Law Review, v. 57, p. 741-780, 2004.

. The debtor in full control- system failure under Chapter 11 of the Bankruptcy Code? Am. Bankr. L.J, v. 99, p.99-126, 1983.

LUNA, Everardo da Cunha. Abuso de direito. 2. ed. Rio de Janeiro: Forense, 1988.

MARCHI, Eduardo C. Silveira. Guia de Metodologia Jurídica (teses, monografias e artigos). Lecce: Edizioni Del Grifo, 2004. 
MARIANO, Álvaro Augusto Camilo. Abuso de voto na recuperação judicial. Tese (Doutorado) -Faculdade de Direito da Universidade de São Paulo, São Paulo, 2012.

MARTIN, Nathalie D. The Role of History and Culture in Developing Bankruptcy and Insolvency Systems: The Perils of Legal Transplantation. B. C. Int'l \& Comp. L. Rev., v. 28, p. 1-77, 2005.

MARTINS-COSTA, Judith. A boa-fé no direito privado: critérios para sua aplicação. São Paulo: Marcial Pons, 2015.

MARTINS, Pedro Baptista. O Abuso do direito e o ato ilícito. Rio de Janeiro: Forense, 2002.

MENEZES CORDEIRO, Antonio Manuel da Rocha. Da boa-fé no direito civil. Coimbra: Almedina, 2013.

MILLER, Harvey R., Corporate Governance in Chapter 11: The Fiduciary Relationship between Directors and Stockholders of Solvent and Insolvent Corporations. Seton Hall L. Rev. v. 23, p. 1467-1515, 1993.

Chapter 11 in transition: from boom to bust and into the future. Am.Bankr. L.J., v. 81, p. 375, 2007.

MILLER, Harvey R.; WAISMAN, Shai Y. Is Chapter 11 bankruptcy? B. C. L. Rev. v. 47, p. 129-181, 2005.

MUNHOZ, Eduardo Secchi. Anotações sobre os limites do poder jurisdicional na apreciação do plano de recuperação judicial. Revista de Direito Bancário e do Mercado de Capitais, v. 10, n. 36, p. 184-199, abr./jun. 2007.

NEDER CEREZETTI, Sheila C. A Recuperação Judicial de Sociedade por Ações. São Paulo, Malheiros, 2012.

O papel dos credores no Bankruptcy Code. Revista de Direito Mercantil, Industrial, Econômico e Financeiro, São Paulo, ano 48, n. 151/152, p.164-186, jan./dez. 2009.

MAFFIOLETI, Emanuelle Urbano (coord.), Dez anos da Lei $n^{\circ} 11.101 / 2005$ : estudos sobre a lei de recuperação e falência. São Paulo: Almedina, 2015.

NUSDEO, Fabio. Curso de economia. São Paulo: Revista dos Tribunais, 1997.

OMAR, Paul J. Reforms to the framework of insolvency law and practice in France:19962006. In: BROC, Katarzyna Gromek; PARRY, Rebecca (orgs.). Corporate Rescue: an Overview of Recent Developments. 2. Ed. Klunwer Law International, 2012.

PAIVA, Luis Fernando Valente de (coord.). Direito Falimentar e a nova Lei de Falências e Recuperação de Empresas. São Paulo: Quartier Latin, 2005. 
PATERSON, Sarah. Rethinking the Role of the Law of Corporate Distress in the TwentyFirst Century. LSE Law, Society and Economy Working Papers, v. 27, 2014.

PAULUS, Christoph G. Global Insolvency Law and the role of multinational institutions. Brook. J. Int'L. L., v. 32, n. 3, p.1-13, 2007.

PLANIOL, Marcel F. Traité élementaire de droit civil. 6. ed., Tomo II, Paris, 1912.

PONTES DE MIRANDA, Francisco Cavalcanti. Tratado de Direito Privado, tomo 53, 2. ed. Rio de Janeiro: Borsoi, 1966.

POSNER, Richard A. Economic Analisys of Law. 7. ed. New York: Aspen Publishers, 2007.

PITOMBO, Antônio Sérgio A. de Moraes; SOUZA JÚNIOR, Francisco Satiro de (Org.). Comentários à Lei de Recuperação de empresa e falência. 2. ed. São Paulo: Revista dos Tribunais, 2008.

PUGLIESI, Adriana Valéria, Direito Falimentar e Preservação da Empresa. São Paulo: Quartier Latin, 2013.

QUEIROZ, Rafael Mafei Rabelo; FEFERBAUM, Marina (coords.), Metodologia jurídica: um roteiro prático para trabalhos de conclusão de curso. São Paulo: Saraiva, 2012.

REALE, Miguel. Lições Preliminares de Direito. 21. ed., rev. e atual. São Paulo: Saraiva, 1994.

REQUIÃO, Rubens. Curso de direito falimentar. São Paulo: Saraiva, 1970. v. 2.

RODRIGUES, Silvio. Direito Civil: responsabilidade. São Paulo: Saraiva, 2007.

ROPPO, Enzo. O Contrato. Coimbra: Almedina, 2009.

RIPERT, Georges. A regra moral nas obrigações civis. 2. ed. São Paulo: Saraiva, 1937

SALOMÃO FILHO, Calixto. O Novo Direito Societário. 2. ed. São Paulo: Malheiros, 2002.

Sociedade anônima: interesse público e privado. Revista de Direito Mercantil, Industrial, Econômico e Financeiro, São Paulo, v. 41, n. 127, p. 7-20, 2002.

- A recuperação de empresas e interesse social. In: PITOMBO, Antônio Sérgio A. de Moraes; SOUZA JÚNIOR, Francisco Satiro de (Org.). Comentários à Lei de Recuperação de empresa e falência. 2. ed. São Paulo: Revista dos Tribunais, 2008.

Breves acenos para uma análise estruturalista do contrato. RDPE- Revista de direito público de economia, Belo Horizonte, v. 5, n. 17, p. 41-74, jan./mar. 2007. 
Sociedade anônima: interesse público e privado. Revista de Direito Mercantil, Industrial, Econômico e Financeiro, São Paulo, v. 41, n. 127, p. 7-20, 2002.

SANTOS, Paulo Penalva, A nova Lei de Falências e de recuperação de empresas: Lei 11.101/05. Rio de Janeiro: Forense, 2006.

SARRA, Janis. Creditor Rights and the Public Interest. Toronto: University of Toronto Press, 2003.

SCALZILLI, João Pedro; SPINELLI, Luis Felipe; TELLECHEA, Rodrigo. Recuperação de empresas e falência: teoria e prática na Lei 11.101/2005. São Paulo: Almedina, 2016.

SCHEFFER, Markus. German Insolvency Law: nothing more than a perfect legal framework? International Business Lawyer, v. 461, 2002.

SERRA, Catarina. O novo regime português da insolvência: uma introdução. 4. ed. Coimbra: Almedina, 2010.

SIMIONATO, Frederico Augusto Monte. A reforma da lei de falências frente à reorganização econômica da empresa. Revista de Direito Mercantil, Industrial Econômico e Financeiro, São Paulo, n. 108, pág. 16-62, outubro/dezembro 1997.

SKEEL JR., David A. Debt's dominion: a history of the bankruptcy law in America, Princeton: Princeton University Press, 2001.

Bankruptcy Phobia. Temple Law Review, v. 82, n. 2, 2009.

SKELL JR, David. A. A evolutionary theory of corporate law and corporate bankruptcy. Vanderbiltlaw Review, v. 51, p. 1353-76, 1998.

STIGLITZ, Joseph, Bankruptcy: some basics economic principles: resolution of financial distress. Washington: Work Bank Institute, 2003. p. 1-23.

SZTAJN, Raquel; SALLES, Marcos Paulo de Almeida; TEIXEIRA, Tarcísio. Direito Empresarial: Estudos em homenagem ao Professor Haroldo Malheiros Duclerc Verçosa. São Paulo: IASP, 2015.

TABB, Charles Jordan. The Law of Bankruptcy. Minnesota: West Academic Publishing 2016.

TEIXEIRA, Egberto Lacerda; GUERREIRO, José Alexandre Tavares Guerreiro. Das sociedades anônimas no direito brasileiro. São Paulo: Livraria e Editora Jurídica J. Bushatsky, 1979.

TOLEDO, Paulo F. C. Salles de. A empresa em crise no Direito Francês e Americano, Dissertação (Mestrado) - Faculdade de Direito da Universidade de São Paulo, São Paulo, 1987. 
TOLEDO, Paulo F. C. Salles de; ABRÃO, Carlos Henrique (coord.), Comentários à Lei de Recuperação de Empresas e Falência. São Paulo: Saraiva. 2005.

TOLEDO, Paulo F. C. Salles de; SATIRO, Francisco (coord.). Direito das Empresas em Crise: Problemas e soluções. São Paulo: Quartier Latin, 2012.

TOLEDO, Paulo Fernando Campos Salles de. Recuperação Judicial, a principal inovação da Lei de Recuperação de Empresas- LRE, Revista do Advogado, v. 83, ano XXV, p. 102-103, 2005.

TUNG, Frederic. Confirmation and Claims Trading. Nw. U.L. Rev., v. 90, p. 1689, 1996.

TZIRULNIK, Luiz. Direito Falimentar. 7. ed. São Paulo: Revista dos Tribunais, 2005.

UNITED NATIONS COMMISSION ON INTERNATIONAL TRADE LAW, Legislative Guide on Insolvency Law, 2005.

VALVERDE, Trajano de Miranda, Comentários à Lei de Falências. v. 1-3. 3. ed. Rio de Janeiro: Revista Forense, 1969.

VAISER, Lidia. El abuso del derecho em los processos concursales. 1. ed. Ad Hoc: Buenos Aires, 2008.

VARELA, João de Matos Antunes. Das obrigações em geral. v. 2. Coimbra: Almedina, 2000. V. 2.

. O Abuso de direito no sistema jurídico brasileiro. Revista de Direito Comparado Luso-Brasileiro, Rio de Janeiro, v. 1, p. 39-52, 1982.

VENOSA, Silvio de Salvo. Abuso de direito. Revista da Faculdade de Direito das Faculdades Metropolitanas Unidas, São Paulo, v. 2, n. 2, p. 251-270, mar. 1988.

XAVIER, Lobo. Anulação de deliberação social e deliberações conexas. Coimbra: Almedina, 1999.

WARREN, Elizabeth. Bankruptcy Policy. U. Chicago. L. Rev., v. 54, p. 775-814, 1987.

1993-1994.

Bankruptcy Policymaking in an Imperfect World. Mich. L. Rev., v. 92, p. 336-387,

WESTBROOK, Jay Lawrence. The Globalisation of Insolvency Reform. N. Z. L. Rev., p. 401-414, 1999.

WORLD BANK. Principles and Guidelines for effective insolvency and creditors rights systems. 2001. 
YARSHELL, Flávio Luiz; PEREIRA, Guilherme Setoguti J. (coord). Processo Societário. São Paulo, Quartier Latin, 2005.

\section{JURISPRUDÊNCIA}

STJ, Segunda Seção, Recurso especial representativo de controvérsia $n^{\circ}$ 1.333.349/SP, Ministro Relator Luis Felipe Salomão, julgamento em 26 de novembro de 2014;

STJ, Terceira Turma, Recurso especial $n^{\circ}$ 1.314.209/SP, Ministra Relatora Nancy Andrighi, julgamento em 22 de abril 2012;

TJRJ, 5 $5^{\mathrm{a}}$ Câmara Cível, Agravo de Instrumento $\mathrm{n}^{\mathrm{o}}$ 0037321-84.2011.8.19.0000, Desembargador Relator Milton Fernandes de Souza, julgamento em 13 de dezembro de 2011;

TJSP, 2 ${ }^{\text {a }}$ Câmara Reservada de Direito Empresarial, Agravo de Instrumento $\mathrm{n}^{\mathbf{o}} 2097008$ 84.2016.8.26.0000, Desembargador Relator Claudio Godoy, julgamento em 13 de março de 2017

TJSP, 2 ${ }^{\text {a }}$ Câmara Reservada de Direito Empresarial, Agravo de Instrumento $\mathrm{n}^{\mathbf{o}}$ 201252609.2016.8.26.0000, Desembargador Relator Caio Marcelo Mendes de Oliveira, julgamento em 13 de fevereiro de 2017;

TJSP, 2 ${ }^{\text {a }}$ Câmara Reservada de Direito Empresarial, Agravo de Instrumento $\mathrm{n}^{\mathbf{o}} 2102479$ 81.2016.8.26.0000, Desembargador Relator Carlos Alberto Garbi, julgamento em 13 de março de 2017;

TJSP, $1^{\text {a }}$ Câmara Reservada de Direito Empresarial, Agravo de Instrumento $\mathrm{n}^{0} 21662636$ 20.2016.0000, Desembargador Relator Carlos Cesar Ciampolini, julgamento em 21 de fevereiro de 2017;

TJSP, $1^{a}$ Câmara Reservada de Direito Empresarial, Agravo de Instrumento $\mathrm{n}^{\circ}$ 216238162.2016.8.26.0000, Desembargador Relator Carlos Cesar Ciampolini, julgamento em 21 de fevereiro de 2017;

TJSP, $2^{a}$ Câmara Reservada de Direito Empresarial, Agravo de Instrumento $\mathrm{n}^{\mathrm{o}}$ 208215910.2016.8.26.0000, Desembargador Relator Claudio Godoy, julgamento em 21 de fevereiro de 2017;

TJSP, 2a Câmara Reservada de Direito Empresarial, Agravo de Instrumento $\mathrm{n}^{\mathrm{o}}$ 205884887.2016.8.26.0000, Desembargador Relator Caio Marcelo Mendes de Oliveira, julgamento em 17 de fevereiro de 2017; 
TJSP, $2^{\text {a }}$ Câmara Reservada de Direito Empresarial, Agravo de Instrumento $\mathrm{n}^{\mathrm{o}} 2127110$ 89.2016.8.26.0000, Desembargador Relator Caio Marcelo Mendes de Oliveira, julgamento em 17 de fevereiro de 2017;

TJSP, 2 ${ }^{\text {a }}$ Câmara Reservada de Direito Empresarial, Agravo de Instrumento $\mathrm{n}^{\mathrm{o}} 2128132$ 85.2016.8.26.0000, Desembargador Relator Caio Marcelo Mendes de Oliveira, julgamento em 17 de fevereiro de 2017;

TJSP, 2a Câmara Reservada de Direito Empresarial, Agravo de Instrumento $\mathrm{n}^{\mathrm{o}} 2128567$ 59.2016.8.26.0000, Desembargador Relator Caio Marcelo Mendes de Oliveira, julgamento em 17 de fevereiro de 2017;

TJSP, 2a Câmara Reservada de Direito Empresarial, Agravo de Instrumento $\mathrm{n}^{\mathrm{o}} 2162922$ 95.2016.8.26.0000, Desembargador Relator Caio Marcelo Mendes de Oliveira, julgamento em 17 de fevereiro de 2017;

TJSP, $1^{\text {a }}$ Câmara Reservada de Direito Empresarial, Agravo de Instrumento $\mathrm{n}^{\mathrm{o}}$ 212012689.2016.8.26.0000, Desembargador Relator Francisco Loureiro, julgamento em 7 de dezembro de 2016;

TJSP, $1^{\text {a }}$ Câmara Reservada de Direito Empresarial, Agravo de Instrumento $\mathrm{n}^{\mathrm{o}}$ 216761185.2016.8.26.0000, Desembargador Relator Francisco Loureiro, julgamento em 7 de dezembro de 2016;

TJSP, $1^{\text {a }}$ Câmara Reservada de Direito Empresarial, Agravo de Instrumento $\mathrm{n}^{\circ} 2167622$ 17.2016.8.26.0000, Desembargador Relator Francisco Loureiro, julgamento em 7 de dezembro de 2016;

TJSP, $2^{\text {a }}$ Câmara Reservada de Direito Empresarial, Agravo de Instrumento $\mathrm{n}^{\circ}$ 226266952.2015.8.26.0000, Desembargador Relator Caio Marcelo Mendes de Oliveira, julgamento em 28 de novembro de 2016;

TJSP, 2 ${ }^{\mathrm{a}}$ Câmara Reservada de Direito Empresarial, Agravo de instrumento $\mathrm{n}^{\mathrm{o}} 2264450$ 12.2015.8.26.0000, Desembargador Relator Caio Marcelo Mendes de Oliveira, julgamento em 28 de novembro de 2016;

TJSP, 2 ${ }^{\text {a }}$ Câmara Reservada de Direito Empresarial, Agravo de Instrumento $\mathrm{n}^{\circ}$ 226300726.2015.8.26.0000, Desembargador Relator Caio Marcelo Mendes de Oliveira, julgamento em 28 de novembro de 2016;

TJSP, $1^{a}$ Câmara Reservada de Direito Empresarial, Agravo de Instrumento $\mathrm{n}^{\circ}$ 207682155.2016.8.26.0000, Desembargador Relator Hamid Bdine, julgamento em 9 de novembro de 2016;

TJSP, 2a Câmara Reservada de Direito Empresarial, Agravo de Instrumento no 22012129 47.2016.8.26.0000, Desembargador Relator Caio Marcelo Mendes de Oliveira, julgamento em 31 de outubro de 2016; 
TJSP, $2^{a}$ Câmara Reservada de Direito Empresarial, Agravo de Instrumento $\mathrm{n}^{\mathbf{0}} 2038336$ 83.2016.8.26.0000, Desembargador Relator Carlos Alberto Garbi, julgamento em 31 de outubro de 2016;

TJSP, 2 ${ }^{\mathrm{a}}$ Câmara Reservada de Direito Empresarial, Agravo de Instrumento $\mathrm{n}^{\mathbf{0}} 2041314$ 33.2016.8.26.0000, Desembargador Relator Carlos Alberto Garbi, julgamento em 31 de outubro de 2016;

TJSP, 2 ${ }^{\mathrm{a}}$ Câmara Reservada de Direito Empresarial, Agravo de Instrumento $\mathrm{n}^{\mathbf{0}}$ 202068623.2016.8.26.0000, Desembargador Relator Carlos Alberto Garbi, julgamento em 31 de outubro de 2016;

TJSP, $2^{\mathrm{a}}$ Câmara Reservada de Direito Empresarial, Agravo de Instrumento $\mathrm{n}^{\mathbf{0}} 2023011$ 68.2016.8.26.0000, Desembargador Relator Carlos Alberto Garbi, julgamento em 31 de outubro de 2016;

TJSP, $2^{\text {a }}$ Câmara Reservada de Direito Empresarial, Agravo de Instrumento $n^{\mathbf{0}} 2023011$ 68.2016.8.26.0000, Desembargador Relator Carlos Alberto Garbi, julgamento em 31 de outubro de 2016;

TJSP, 2 ${ }^{\mathrm{a}}$ Câmara Reservada de Direito Empresarial, Agravo de Instrumento $\mathrm{n}^{\mathbf{0}} 2026392$ 84.2016.8.26.0000, Desembargador Relator Carlos Alberto Garbi, julgamento em 31 de outubro de 2016;

TJSP, 2 ${ }^{\mathrm{a}}$ Câmara Reservada de Direito Empresarial, Agravo de Instrumento $\mathrm{n}^{\mathbf{0}} 2025533$ 68.2016.8.26.0000, Desembargador Relator Carlos Alberto Garbi, julgamento em 31 de outubro de 2016;

TJSP, 2 ${ }^{\mathrm{a}}$ Câmara Reservada de Direito Empresarial, Agravo de Instrumento $\mathrm{n}^{\mathrm{o}}$ 202589655.2016.8.26.0000, Desembargador Relator Carlos Alberto Garbi, julgamento em 31 de outubro de 2016;

TJSP, 2 ${ }^{\text {a }}$ Câmara Reservada de Direito Empresarial, Agravo de Instrumento $\mathrm{n}^{\circ}$ 202618925.2016.8.26.0000, Desembargador Relator Carlos Alberto Garbi, julgamento em 31 de outubro de 2016;

TJSP, 2a Câmara Reservada de Direito Empresarial, Agravo de Instrumento n ${ }^{\circ} 2040299$ 29.2016.8.26.0000, Desembargador Relator Carlos Alberto Garbi, julgamento em 31 de outubro de 2016;

TJSP, 2a Câmara Reservada de Direito Empresarial, Agravo de Instrumento ${ }^{\circ}$ 204073840.2016.8.26.0000, Desembargador Relator Carlos Alberto Garbi, julgamento em 31 de outubro de 2016;

TJSP, $2{ }^{\text {a }}$ Câmara Reservada de Direito Empresarial, Agravo de Instrumento $\mathrm{n}^{\mathrm{o}} 2041542$ 08.2016.8.26.0000, Desembargador Relator Carlos Alberto Garbi, julgamento em 31 de outubro de 2016; 
TJSP, $2^{\text {a }}$ Câmara Reservada de Direito Empresarial, Agravo de Instrumento $\mathrm{n}^{\mathrm{o}} 2040805$ 05.2016.8.26.0000, Desembargador Relator Carlos Alberto Garbi, julgamento em 31 de outubro de 2016;

TJSP, 2 ${ }^{\text {a }}$ Câmara Reservada de Direito Empresarial, Agravo de Instrumento $\mathrm{n}^{\mathbf{o}}$ 204083103.2016.8.26.0000, Desembargador Relator Carlos Alberto Garbi, julgamento em 31 de outubro de 2016;

TJSP, 2a Câmara Reservada de Direito Empresarial, Agravo de Instrumento $\mathrm{n}^{\mathrm{o}}$ 205504681.2016.8.26.0000, Desembargador Relator Carlos Alberto Garbi, julgamento em 31 de outubro de 2016;

TJSP, 2 ${ }^{\text {a }}$ Câmara Reservada de Direito Empresarial, Agravo de Instrumento $\mathrm{n}^{\mathrm{o}} 2041618$ 32.2016.8.26.0000, Desembargador Relator Carlos Alberto Garbi, julgamento em 31 de outubro de 2016;

TJSP, 2 ${ }^{\text {a }}$ Câmara Reservada de Direito Empresarial, Agravo de Instrumento $\mathrm{n}^{\mathrm{o}} 2040940$ 17.2016.8.26.0000, Desembargador Relator Carlos Alberto Garbi, julgamento em 31 de outubro de 2016;

TJSP, 2 ${ }^{\text {a }}$ Câmara Reservada de Direito Empresarial, Agravo de Instrumento n ${ }^{\circ}$ 204107966.2016.8.26.0000, Desembargador Relator Carlos Alberto Garbi, julgamento em 31 de outubro de 2016;

TJSP, 2 ${ }^{\text {a }}$ Câmara Reservada de Direito Empresarial, Agravo de Instrumento $\mathrm{n}^{\mathbf{0}} 2041512$ 70.2016.8.26.0000, Desembargador Relator Carlos Alberto Garbi, julgamento em 31 de outubro de 2016;

TJSP, 2 ${ }^{\text {a }}$ Câmara Reservada de Direito Empresarial, Agravo de Instrumento $\mathrm{n}^{\mathrm{o}}$ 204083103.2016.8.26.0000, Desembargador Relator Carlos Alberto Garbi, julgamento em 31 de outubro de 2016;

TJSP, $1^{\text {a }}$ Câmara Reservada de Direito Empresarial, Agravo de Instrumento $\mathrm{n}^{\circ} 2112611$ 03.2016.8.26.0000, Desembargador Relator Carlos Cesar Ciampolini, julgamento em 21 de setembro de 2016;

TJSP, $1^{\text {a }}$ Câmara Reservada de Direito Empresarial, Agravo de Instrumento $\mathrm{n}^{\circ}$ 201758575.2016.8.26.0000, Desembargador Relator Hamid Bdine, julgamento em 17 de agosto de 2016;

TJSP, $2^{a}$ Câmara Reservada de Direito Empresarial, Agravo de Instrumento $\mathrm{n}^{\circ}$ 221275094.2015.8.26.0000, Desembargador Relator Caio Marcelo Mendes de Oliveira, julgamento em 15 de agosto de 2016;

TJSP, $2^{\text {a }}$ Câmara Reservada de Direito Empresarial, Agravo de Instrumento $\mathrm{n}^{\mathrm{o}} 2219188$ 39.2015.8.26.0000, Desembargador Relator Caio Marcelo Mendes de Oliveira, julgamento em 15 de agosto de 2016; 
TJSP, $1^{\text {a }}$ Câmara Reservada de Direito Empresarial, Agravo de Instrumento $\mathrm{n}^{\mathrm{o}} 2023163$ 19.2016.8.26.0000, Desembargador Relator Hamid Bdine, julgamento em 13 de julho de 2016;

TJSP, $1^{a}$ Câmara Reservada de Direito Empresarial, Agravo de Instrumento $\mathrm{n}^{\mathbf{0}} 2022697$ 25.2016.8.26.0000, Desembargador Relator Hamid Bdine, julgamento em 13 de julho de 2016;

TJSP, 2 ${ }^{\text {a }}$ Câmara Reservada de Direito Empresarial, Agravo de Instrumento ${ }^{\circ}$ 204334963.2016.26.8.0000, Desembargador Relator Ricardo Negrão, julgamento em 27 de junho de 2016;

TJSP, $1^{\text {a }}$ Câmara Reservada de Direito Empresarial Agravo de Instrumento n²00460074.2016.8.26.0000, Desembargador Relator Teixeira Leite, julgamento em 15 de junho de 2016;

TJSP, $1^{a}$ Câmara Reservada de Direito Empresarial Agravo de Instrumento $\mathrm{n}^{\mathrm{o}} 2241820$ 59.2015.8.26.0000, Desembargador Relator Teixeira Leite, julgamento em 15 de junho de 2016;

TJSP, $1^{\text {a }}$ Câmara Reservada de Direito Empresarial Agravo de Instrumento $\mathrm{n}^{\mathbf{0}} 2242116$ 81.2015.8.26.0000, Desembargador Relator Teixeira Leite, julgamento em 15 de junho de 2016;

TJSP, $1^{\text {a }}$ Câmara Reservada de Direito Empresarial Agravo de Instrumento $\mathrm{n}^{\mathbf{0}} 2242478$ 83.2015.8.26.0000, Desembargador Relator Teixeira Leite, julgamento em 15 de junho de 2016;

TJSP, $1^{a}$ Câmara Reservada de Direito Empresarial Agravo de Instrumento $\mathrm{n}^{\mathrm{o}} 2273787$ 25.2015.8.26.000, Desembargador Relator Teixeira Leite, julgamento em 15 de junho de 2016;

TJSP, $1^{\text {a }}$ Câmara Reservada de Direito Empresarial, Agravo de Instrumento $\mathrm{n}^{\circ}$ 226247807.2016.8.26.0000, Desembargador Relator Hamid Bdine, julgamento em 3 de junho de 2016;

TJSP, 2 ${ }^{\mathrm{a}}$ Câmara Reservada de Direito Empresarial, Agravo de Instrumento $\mathrm{n}^{\mathrm{o}} 2067192$ 91.2015.8.26.0000, Desembargador Relator Caio Marcelo Mendes de Oliveira, julgamento em 25 de maio de 2016;

TJSP, $2^{\text {a }}$ Câmara Reservada de Direito Empresarial, Agravo de Instrumento $\mathrm{n}^{\mathbf{0}} 2230018$ 64.2015.8.26.0000, Desembargador Relator Carlos Alberto Garbi, julgamento em 25 de maio de 2016;

TJSP, $1^{\text {a }}$ Câmara Reservada de Direito Empresarial, Agravo de Instrumento $\mathrm{n}^{\circ}$ 201756584.2016.8.26.0000, Desembargador Relator Enio Zuliani, julgamento em 18 de maio de 2016. 
TJSP, $1^{\text {a }}$ Câmara Reservada de Direito Empresarial Agravo de Instrumento n²00460074.2016.8.26.0000, Desembargador Relator Teixeira Leite, julgamento em 15 de junho de 2016;

TJSP, $1^{\text {a }}$ Câmara Reservada de Direito Empresarial Agravo de Instrumento $\mathrm{n}^{\mathrm{o}}$ 224182059.2015.8.26.0000, Desembargador Relator Teixeira Leite, julgamento em 15 de junho de 2016;

TJSP, $1^{\text {a }}$ Câmara Reservada de Direito Empresarial Agravo de Instrumento $\mathrm{n}^{\circ}$ 224211681.2015.8.26.0000, Desembargador Relator Teixeira Leite, julgamento em 15 de junho de 2016;

TJSP, $1^{\text {a }}$ Câmara Reservada de Direito Empresarial Agravo de Instrumento $\mathrm{n}^{\mathrm{o}}$ 224247883.2015.8.26.0000, Desembargador Relator Teixeira Leite, julgamento em 15 de junho de 2016;

TJSP, $1^{\text {a }}$ Câmara Reservada de Direito Empresarial Agravo de Instrumento $\mathrm{n}^{\mathbf{0}}$ 227378725.2015.8.26.000, Desembargador Relator Teixeira Leite, julgamento em 15 de junho de 2016;

TJSP, $1^{\text {a }}$ Câmara Reservada de Direito Empresarial Agravo de Instrumento $\mathrm{n}^{\mathrm{o}} 2000664$ 41.2016.26.0000, Desembargador Relator Teixeira Leite, julgamento em 18 de maio de 2016;

TJSP, $1^{\text {a }}$ Câmara Reservada de Direito Empresarial, Agravo de Instrumento $\mathrm{n}^{\mathrm{o}}$ 225487310.2015.8.26.0000, Desembargador Relator Teixeira Leite, julgamento em 6 de abril de 2016;

TJSP, 2a Câmara Reservada de Direito Empresarial, Agravo de Instrumento $\mathrm{n}^{\mathbf{o}} 2180362$ 41.2015.8.26.0000, Desembargador Relator Ricardo Negrão, julgamento em 29 de fevereiro de 2016;

TJSP, $1^{a}$ Câmara Reservada de Direito Empresarial, Agravo de Instrumento $\mathrm{n}^{\mathrm{o}} 2172104$ 42.2015.8.26.0000, Desembargador Relator Teixeira Leite, julgamento em 16 de dezembro de 2015;

TJSP, 2 ${ }^{\text {a }}$ Câmara Reservada de Direito Empresarial, Agravo de Instrumento $\mathrm{n}^{\mathrm{o}}$ 208904122.2015.2015.8.26.0000, Desembargador Relator Ricardo Negrão, julgamento em 2 de dezembro de 2015;

TJSP, 2a Câmara Reservada de Direito Empresarial, Agravo de Instrumento $\mathrm{n}^{\mathrm{o}}$ 215079902.2015.8.26.0000, Desembargador Relator Campos Mello, julgamento em 16 de novembro de 2015;

TJSP, $2^{\text {a }}$ Câmara Reservada de Direito Empresarial, Agravo de Instrumento $\mathrm{n}^{\mathbf{0}}$ 201499159.2014.8.26.0000, Desembargador Relator Ramon Mateo Junior, julgamento em 9 de setembro de 2015; 
TJSP, $2^{\text {a }}$ Câmara Reservada de Direito Empresarial, Agravo de Instrumento $\mathrm{n}^{\mathrm{o}} 2173004$ 59.2014.8.26.0000, Desembargador Relator Araldo Telles, julgamento em 18 de maio de 2015 ;

TJSP, 2 ${ }^{\mathrm{a}}$ Câmara Reservada de Direito Empresarial, Agravo de Instrumento $\mathrm{n}^{\mathbf{0}}$ 217299160.2014.8.26.0000, Desembargador Relator Araldo Telles, julgamento em 18 de maio de 2015;

TJSP, 2 ${ }^{\mathrm{a}}$ Câmara Reservada de Direito Empresarial, Agravo de Instrumento $\mathrm{n}^{\mathbf{0}} 2172879$ 91.2014.8.26.0000, Desembargador Relator Araldo Telles, julgamento em 18 de maio de 2015;

TJSP, $1^{\text {a }}$ Câmara Reservada de Direito Empresarial, Agravo de Instrumento $\mathrm{n}^{\mathbf{0}} 2135586$ 87.2014.8.26.0000, Desembargador Relator Teixeira Leite, julgamento em 29 de abril de 2015;

TJSP, $2^{\text {a }}$ Câmara Reservada de Direito Empresarial, Agravo de Instrumento $\mathrm{n}^{\mathbf{0}}$ 206052997.2013.8.26.0000, Desembargador Relator Ricardo Negrão, julgamento em 10 de abril de 2015;

TJSP, 2 ${ }^{\mathrm{a}}$ Câmara Reservada de Direito Empresarial, Agravo de Instrumento $\mathrm{n}^{\mathbf{0}} 2060520$ 38.2013.8.26.0000, Desembargador Relator Ricardo Negrão, julgamento em 10 de abril de 2015;

TJSP, 2 ${ }^{\mathrm{a}}$ Câmara Reservada de Direito Empresarial, Agravo de Instrumento $\mathrm{n}^{\mathrm{o}} 0146029$ 052012.8.26.0000, Desembargador Relator Araldo Telles, julgamento em 10 de abril de 2015;

TJSP, $2^{\mathrm{a}}$ Câmara Reservada de Direito Empresarial, Agravo de Instrumento $\mathrm{n}^{\mathrm{o}} 2158969$ 94.2014.8.26.000, Desembargador Relator Tasso Duarte de Melo, julgamento em 7 de abril de 2015;

TJSP, 2 ${ }^{\mathrm{a}}$ Câmara Reservada de Direito Empresarial, Agravo de Instrumento $\mathrm{n}^{\mathbf{0}} 2039822$ 74.2014.8.26.0000, Desembargador Relator Ramon Mateo Junior, julgamento em 16 de março de 2015;

TJSP, 2 ${ }^{\mathrm{a}}$ Câmara Reservada de Direito Empresarial, Agravo de Instrumento $\mathrm{n}^{\mathbf{0}} 2050098$ 67.2014.8.26.0000, Desembargador Relator Ramon Mateo Junior, julgamento em 16 de março de 2015;

TJSP, $2^{a}$ Câmara Reservada de Direito Empresarial, Agravo de Instrumento $\mathrm{n}^{\mathbf{0}}$ 217003486.2014.8.26.0000, Desembargador Relator Ramon Mateo Júnior, julgamento em 11 de fevereiro de 2015;

TJSP, 2 ${ }^{\text {a }}$ Câmara Reservada de Direito Empresarial, Agravo de instrumento n²12943508.2014.8.26.0000, Desembargador Relator Ricardo Negrão, julgamento em 10 de dezembro de 2014; 
TJSP, $2^{\text {a }}$ Câmara Reservada de Direito Empresarial, Agravo de Instrumento $\mathrm{n}^{\mathrm{o}}$ 212169414.2014.8.26.0000, Desembargador Relator Ramon Mateo Junior, julgamento em 10 de dezembro de 2014;

TJSP, $1^{\text {a }}$ Câmara Reservada de Direito Empresarial, Agravo de Instrumento $\mathrm{n}^{\mathbf{o}}$ 206857019.2014.8.26.000, Desembargador Relator Cláudio Godoy, julgamento em 9 de dezembro de 2014;

TJSP, $1^{\text {a }}$ Câmara Reservada de Direito Empresarial, Agravo de Instrumento $\mathrm{n}^{\circ}$ 010666186.2012.8.26.0000, Desembargador Relator Francisco Loureiro, julgamento em 3 de julho de 2014;

TJSP, $1^{\text {a }}$ Câmara Reservada de Direito Empresarial, Agravo de Instrumento $\mathrm{n}^{\mathrm{o}}$ 015552354.2013.8.26.0000, Desembargador Relator Teixeira Leite, julgamento em 6 de fevereiro de 2014;

TJSP, $1^{\text {a }}$ Câmara Reservada de Direito Empresarial, Agravo de Instrumento $\mathrm{n}^{\circ}$ 016454102.2013.8.26.0000, Desembargador Relator Fortes Barbosa, julgamento em 6 de fevereiro de 2014;

TJSP, $1^{\text {a }}$ Câmara Reservada de Direito Empresarial Agravo de Instrumento n ${ }^{\circ} 0163333$ 80.2013.8.26.0000, Desembargador Relator Fortes Barbosa, julgamento em 6 de fevereiro de 2014;

TJSP, 2 ${ }^{\text {a }}$ Câmara Reservada de Direito Empresarial, Agravo de Instrumento $\mathrm{n}^{\mathbf{0}}$ 09907676.2013.8.26.0000, Desembargador Relator José Reynaldo, julgamento em 3 de fevereiro de 2014;

TJSP, 2 ${ }^{\text {a }}$ Câmara Reservada de Direito Empresarial, Agravo de Instrumento $\mathrm{n}^{\circ}$ 010084407.2013.8.26.0000, Desembargador Relator José Reynaldo, julgamento em 3 de fevereiro de 2014;

TJSP, $2^{a}$ Câmara Reservada à Falência e Recuperação, Agravo de Instrumento n ${ }^{\circ} 0308398$ 77.2011, Desembargador Relator Ricardo Negrão, julgamento em 6 de maio de 2013;

TJSP, $1^{\text {a }}$ Câmara Reservada de Direito Empresarial, Agravo de Instrumento $\mathrm{n}^{\circ}$ 018306144.2012.8.26.0000, Desembargador Relator Francisco Loureiro, julgamento em 11 de dezembro de 2012;

TJSP, 2 ${ }^{\text {a }}$ Câmara Reservada de Direito Empresarial, Agravo de Instrumento $\mathrm{n}^{\mathrm{o}} 0031268$ 58.2012.8.26.0000, Desembargadora Relatora Ligia Araújo Bisogni, julgamento em 16 de outubro de 2012;

TJSP, 2 ${ }^{\text {a }}$ Câmara Reservada de Direito Empresarial, Agravo de Instrumento $\mathrm{n}^{\circ}$ 007689925.2012.8.26.0000, Desembargadora Relatora Ligia Araújo Bisogni, julgamento em 7 de agosto de 2012; 
TJSP, Câmara Especial de Falência e Recuperação Judicial, Agravo de Instrumento $\mathrm{n}^{\mathbf{o}}$ 9037840-18.2005.8.26.0000, Desembargador Relator Manoel Pereira Calças, julgamento em 15 de março de 2006;

TJSP, Câmara Especial de Falência e Recuperação Judicial, Agravo de Instrumento ${ }^{\circ}$ 9037825-49.2005.8.26.0000, Câmara Especial de Falência e Recuperação Judicial, Desembargador Relator Manoel Pereira Calças, julgamento em 15 de março 2006. 